\title{
Dopamine Release Dynamics in the Tuberoinfundibular Dopamine System
}

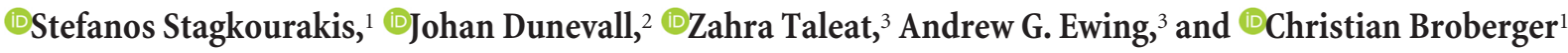 \\ ${ }^{1}$ Department of Neuroscience, Karolinska Institutet, 17165 Stockholm, Sweden, ${ }^{2}$ Department of Chemistry and Chemical Engineering, Chalmers University \\ of Technology, 41296 Gothenburg, Sweden, and ${ }^{3}$ Department of Chemistry and Molecular Biology, University of Gothenburg, 41296 Gothenburg, Sweden
}

The relationship between neuronal impulse activity and neurotransmitter release remains elusive. This issue is especially poorly understood in the neuroendocrine system, with its particular demands on periodically voluminous release of neurohormones at the interface of axon terminals and vasculature. A shortage of techniques with sufficient temporal resolution has hindered real-time monitoring of the secretion of the peptides that dominate among the neurohormones. The lactotropic axis provides an important exception in neurochemical identity, however, as pituitary prolactin secretion is primarily under monoaminergic control, via tuberoinfundibular dopamine (TIDA) neurons projecting to the median eminence (ME). Here, we combined electrical or optogenetic stimulation and fast-scan cyclic voltammetry to address dopamine release dynamics in the male mouse TIDA system. Imposing different discharge frequencies during brief $(3 \mathrm{~s})$ stimulation of TIDA terminals in the ME revealed that dopamine output is maximal at $10 \mathrm{~Hz}$, which was found to parallel the TIDA neuron action potential frequency distribution during phasic discharge. Over more sustained stimulation periods ( $150 \mathrm{~s}$ ), maximal output occurred at $5 \mathrm{~Hz}$, similar to the average action potential firing frequency of tonically active TIDA neurons. Application of the dopamine transporter blocker, methylphenidate, significantly increased dopamine levels in the ME, supporting a functional role of the transporter at the neurons' terminals. Lastly, TIDA neuron stimulation at the cell body yielded perisomatic release of dopamine, which may contribute to an ultrafast negative feedback mechanism to constrain TIDA electrical activity. Together, these data shed light on how spiking patterns in the neuroendocrine system translate to vesicular release toward the pituitary and identify how dopamine dynamics are controlled in the TIDA system at different cellular compartments.

Key words: arcuate nucleus; dopamine release; frequency coding; FSCV; hypothalamus; tuberoinfundibular

Significance Statement

A central question in neuroscience is the complex relationship between neuronal discharge activity and transmitter release. By combining optogenetic stimulation and voltammetry, we address this issue in dopamine neurons of the neuroendocrine system, which faces particular spatiotemporal demands on exocytotic release; large amounts of neurohormone need to be secreted into the portal capillaries with precise timing to adapt to physiological requirements. Our data show that release is maximal around the neurons' default firing frequency. We further provide support for functional dopamine transport at the neurovascular terminals, shedding light on a long-standing controversy about the existence of neuroendocrine transmitter reuptake. Finally, we show that dopamine release occurs also at the somatodendritic level, providing a substrate for an ultrashort autoregulatory feedback loop.

\section{Introduction}

The relationship between neuronal impulse traffic and the amount of transmitter released at the axonal terminal has en-

Received Sept. 11, 2018; revised Jan. 6, 2019; accepted Jan. 9, 2019.

Author contributions: S.S., J.D., Z.T., A.G.E., and C.B. designed research; S.S., J.D., and Z.T. performed research;

S.S. and C.B. analyzed data; S.S. wrote the first draft of the paper; S.S., J.D., Z.T., A.G.E., and C.B. edited the paper; J.D., Z.T., and A.G.E. contributed unpublished reagents/analytic tools.

This work was supported by European Research Council Starting Grant ENDOSWITCH 261286, Swedish Research Council 2014-3906, Strategic Research Program in Diabetes at Karolinska Institutet, Hjärnfonden (Swedish Brain Foundation), Novo Nordisk Fonden, Karolinska Institutet internal funds to C.B., European Research Council Advanced Grant, and the Swedish Research Council and the Knut and Alice Wallenberg Foundation to A.G.E. We thank Paul gaged neuroscience since the initial description of quantal release (Del Castillo and Katz, 1954). A question triggered by these seminal observations on the effects of a single action potential was how different patterns and frequencies of discharge translate into

Williams for providing insightful suggestions on the manuscript; Elin Dahlberg and Sandra Azami for expert technical support; and Dr. Nils-Göran Larsson for generously sharing DAT-Cre mice.

The authors declare no competing financial interests.

S. Stagkourakis's present address: Department of Biology and Biological Engineering, Caltech, 91125 Pasadena, USA.

Correspondence should be addressed to Stefanos Stagkourakis at stefanos.stagkourakis@caltech.edu or Christian Broberger at christian.broberger@ki.se.

https://doi.org/10.1523/JNEUROSCI.2339-18.2019

Copyright $\odot 2019$ the authors 
neurotransmitter exocytosis. The conversion from electrical (action potential) to chemical $\left(\mathrm{Ca}^{2+}\right.$-dependent vesicle release and subsequent receptor binding) identity of the neuronal signal introduces several nonlinearities into the process, which complicate the relationship between discharge pattern and secretion. This issue has been addressed in the well-characterized dopaminergic substantia nigra and ventral tegmental area populations, projecting to the caudate-putamen and nucleus accumbens, respectively, revealing the frequency dependence of dopamine output (L. Zhang et al., 2009; Bass et al., 2010). Thus, mesencephalic dopamine terminals exhibit a preferred frequency for optimal neurotransmitter output. Such a mechanism allows neurons to recruit different vesicle and neurotransmitter pools (Iverfeldt et al., 1989; Liu et al., 2011; Doussau et al., 2017), increasing the computational capacity of individual cells. It also provides a safety mechanism, as low activity often will not translate to substantial output (Ngodup et al., 2015).

The neuroendocrine system exhibits several features that distinguishes it from canonical CNS circuits. Instead of a postsynaptic neuron, the targets of the parvocellular systems consist of the endocrine cells of the anterior pituitary gland, which the releasing and inhibiting factors of the neuroendocrine neurones reach by way of the portal capillaries following release at the neurovascular interface (Harris, 1948a,b). The demands on neurohormone volume that follow from this structural organization likely differ substantially from those required to elicit action within the prototypical synapse. Furthermore, the secretion of signal substances into the bloodstream rather than into a confined synaptic cleft suggests that conditions for signal substance reuptake, if it occurs at all, may be different. However, these issues have been difficult to explore because of the lack of highresolution techniques in the temporal domain to quantitatively measure release of neuropeptides and/or neurohormones (with rare exceptions; Glanowska et al., 2012).

Among the hypothalamo-pituitary systems, the lactotropic axis stands out, however, because of its inhibitory effect on target cells and the monoaminergic nature of its chemical signal. Tuberoinfundibular dopamine (TIDA) neurons located in the dorsomedial arcuate nucleus (dmArc) provide a powerful suppressive influence on pituitary lactotrope cells, which produce the hormone, prolactin (Lyons and Broberger, 2014; Grattan, 2015). Prolactin, in turn, plays an important role in, for example, reproduction. A surge in circulating prolactin during late pregnancy and lactation triggers several important physiological functions in the mother, including lactation and maternal care (Grattan, 2015). Dopamine, released in the median eminence (ME) for passage to the hypophyseal portal blood circulation, tonically inhibits the lactotropes through dopamine D2-type receptors (Gudelsky, 1981; Malgaroli et al., 1987; Israel et al., 1990; Lledo et al., 1990; Stefaneanu et al., 2000). Recent studies have revealed distinguishing electrophysiological characteristics of TIDA cells (Lyons et al., 2010), including the capacity for a variable repertoire of firing frequencies in mouse neurons (Romanò et al., 2013; Stagkourakis et al., 2018).

Dopamine release can be monitored with high temporal precision and chemical specificity through fast-scan cyclic voltammetry (FSCV) (Baur et al., 1988; Robinson et al., 2003; Rodeberg et al., 2017). Here, we used electrical (Garris et al., 1997) and optogenetic stimulation (Brimblecombe et al., 2015; Melchior et al., 2015) to impose different discharge protocols upon mouse TIDA neurons and recorded the resultant dopamine release at different cellular compartments. The results provide evidence for frequency optimization, functional reuptake through the dopa- mine transporter (DAT) at TIDA terminals, and a recently proposed ultrashort autoinhibitory feedback loop (Stagkourakis et al., 2016).

\section{Materials and Methods}

Animals. All animal experiments had received approval from the local ethical board, Stockholms Norra Djurförsöksetiska Nämnd, and were performed in accordance with the European Communities Council Directive of November 24, 1986 (86/609/EEC). WT mice with C57BL/6J and $\mathrm{BALB} / \mathrm{c}$ background were used, in addition to previously generated C57BL/6J Slc6a ${ }^{\text {Cre }}$ (DAT-Cre) knock-in (Ekstrand et al., 2007) and floxed-tdTomato mice (The Jackson Laboratory, strain datasheet 007909). Animals were group-housed, up to 5 per cage, in a temperaturecontrolled $\left(23^{\circ} \mathrm{C}\right)$ and humidity-controlled (55\%) environment, in a $12 / 12 \mathrm{~h}$ light/ dark cycle with ad libitum access to food and water. Cages were changed on a weekly basis.

Viral vectors. For channelrhodopsin in vitro optogenetic studies animals were microinjected (see below) in the dmArc with $250 \mathrm{nl}$ of AAV5-EF1a-DIO-hChR2(H134R)-eYFP-WPRE-hGH (Addgene, 20298) $8.41 \times 10^{12}$ genomic copies per milliliter. Control groups were injected with $250 \mathrm{nl}$ of AAV5-EF1a-DIO-eYFP-WPRE-hGH (Addgene, 27056) $5.82 \times 10^{12}$ genomic copies per milliliter. The ChR2 and control eYFP AAV5s were prepared by the University of Pennsylvania Vector Core.

Stereotactic surgery and viral gene transfer. Adult DAT-Cre male mice of 3-6 months age (sexually inexperienced) were stereotactically injected with a virus (see below) and subsequently individually housed for 2 weeks after surgery. Animals were anesthetized with isoflurane (1\%-5\%) and placed in a stereotaxic frame (David Kopf Instruments). Virus was bilaterally injected into the dmArc using a pulled glass capillary (World Precision Instruments) by nanoliter pressure injection at a flow rate of 50 nl per minute (Micro4 controller, World Precision Instruments; Nanojector II, Drummond Scientific). Stereotactic injection coordinates (bregma: $-1.8 \mathrm{~mm}$, midline $\pm 0.1 \mathrm{~mm}$, dorsal surface $-5.5 \mathrm{~mm}$ ) to target the dmArc were obtained from the Paxinos and Franklin atlas (Franklin and Paxinos, 2008). The rostrocaudal extent of viral infections was confined to the dmArc, and transduced DAT positive neurons were typically found between $-1.5 \mathrm{~mm}$ and $-2.00 \mathrm{~mm}$ from bregma, yielding two useful brain slices per animal.

Brain slice electrophysiology. Acute slices of the mediobasal hypothalamus were prepared from adult DAT-tdTomato mice. Slices were cut on a vibratome (Leica Microsystems VT1000S) to $250 \mu \mathrm{m}$ thickness and continuously perfused with oxygenated aCSF containing the following (in m): $127 \mathrm{NaCl}, 2.0 \mathrm{KCl}, 1.2 \mathrm{NaH}_{2} \mathrm{PO}_{4}, 26 \mathrm{NaHCO}_{3}, 1.3 \mathrm{MgCl}_{2}, 2.4$ $\mathrm{CaCl}_{2}$, and $10 \mathrm{D}$-glucose, at $32 \pm 1^{\circ} \mathrm{C}$ during recording. Each slice was exposed only to a single bath application of pharmacological compounds and was used for a single experiment. Whole-cell current- and voltageclamp recordings were performed with micropipettes filled with intracellular solution containing the following (in $\mathrm{mM}$ ), $140 \mathrm{~K}$-gluconate, 10 $\mathrm{KCl}, 10$ HEPES, 10 EGTA, and $2 \mathrm{Na}_{2} \mathrm{ATP}, \mathrm{pH} 7.3$, with $\mathrm{KOH}$. Recordings were performed using a Multiclamp 700B amplifier, a DigiData 1440 digitizer, and pClamp 10.2 software (Molecular Devices). Slow and fast capacitative components were semiautomatically compensated. Access resistance was monitored throughout the experiments, and neurons in which the series resistance exceeded $15 \mathrm{~m} \Omega$ or changed $\geq 20 \%$ were excluded from further analysis. Liquid junction potential was $16.4 \mathrm{mV}$ and not compensated. The recorded current was sampled at $20 \mathrm{kHz}$.

For in vitro optogenetics during slice whole-cell recordings, photostimulation was generated through a $3.4 \mathrm{~W} 447 \mathrm{~nm}$ LED mounted on the microscope oculars and delivered through the objective lens. Photostimulation was controlled via the analog outputs of a DigiData 1440A, enabling control over the duration and intensity. The photostimulation diameter through the objective lens was $\sim 350 \mu \mathrm{m}$ with illumination intensity typically scaled to $3 \mathrm{~mW} / \mathrm{mm}^{2}$. MATLAB (The MathWorks) and OriginPro 8 (OriginLab) were used for electrophysiological data analysis.

Immunofluorescence. Mice were anesthetized with sodium pentobarbital (200 mg/kg, i.p., Sanofi-Aventis), then transcardially perfused with $10 \mathrm{ml} \mathrm{Ca}^{2+}$-free Tyrode's solution $\left(37^{\circ} \mathrm{C}\right)$ containing $0.2 \%$ heparin, fol- 
lowed by $10 \mathrm{ml}$ fixative (4\% PFA and $0.4 \%$ picric acid in $0.16 \mathrm{M}$ PBS, $37^{\circ} \mathrm{C}$ ), and then $50 \mathrm{ml}$ ice-cold fixative. Whole brains were dissected, immersed in ice-cold fixative for $90 \mathrm{~min}$, and then stored in $0.1 \mathrm{M} \mathrm{PBS}$, $\mathrm{pH} 7.4$, containing $20 \%$ sucrose, $0.02 \%$ bacitracin, and $0.01 \%$ sodium azide for $3 \mathrm{~d}$, before freezing with $\mathrm{CO}_{2}$. Coronal sections were cut at a thickness of $14 \mu \mathrm{m}$ using a cryostat (Microm) and thaw-mounted onto gelatin-coated glass slides. For indirect immunofluorescence staining (performed at room temperature unless otherwise specified), air-dried sections were washed in $0.01 \mathrm{M}$ PBS for $30 \mathrm{~min}$ before incubation with the primary antibody diluted in PBS containing $0.3 \%$ Triton X-100 and $1 \%$ BSA for $16 \mathrm{~h}$ at $4^{\circ} \mathrm{C}$. The slides were then washed for $30 \mathrm{~min}$ in PBS followed by $2 \mathrm{~h}$ incubation with Alexa-488-conjugated donkey antirabbit secondary antisera (1:500; Invitrogen). Immunohistochemistry for pSTAT5: Before immunofluorescence staining, antigen retrieval was performed by incubating sections for $15 \mathrm{~min}$ in citric acid, $\mathrm{pH}$ 7.4, at $80^{\circ} \mathrm{C}$, and then cooled at room temperature for a further $30 \mathrm{~min}$. After a $1 \% \mathrm{H}_{2} \mathrm{O}_{2}$ Tris-buffered wash, sections were incubated in rabbit pSTAT5 primary antibody (pSTAT5 Tyr 694, catalog \#C11C5, 1:500; Cell Signaling Technology) for $72 \mathrm{~h}$ at $4^{\circ} \mathrm{C}$. Primary antibody incubation was followed by Cy5-conjugated donkey anti-rabbit secondary antisera (1:500; Invitrogen). TH immunoreactivity was detected via anti- $\mathrm{TH}$ antiserum (1:2000; raised in rabbit, AB152, Millipore), and was followed by Alexa488-conjugated goat raised anti-rabbit secondary antisera (1: 500; Invitrogen). Slides were incubated with the nuclear marker DAPI (Invitrogen) diluted 1: 10,000 in PBS for 5 min before a final wash for $30 \mathrm{~min}$ in PBS, and mounted with glycerol containing (2.5\% DABCO; Sigma-Aldrich).

TIDA cell identification in C57 WT mice. TIDA neuron recordings from C57 WT mice were performed in dmArc using intracellular solution containing $0.2 \%$ Neurobiotin. After recording, slices were placed in fixative (4\% PFA/ $0.16 \%$ picric acid), washed in PBS, and incubated at $4^{\circ} \mathrm{C}$ for $72 \mathrm{~h}$ in a solution containing FITC-conjugated avidin (1:2500, 43-4411, Zymed) and rabbit anti-TH immunoglobulin (1:2000, AB152, Millipore). Following washing, slices were incubated in secondary Alexa594-conjugated donkey-anti-rabbit antiserum (1:500; Invitrogen; $\mathrm{A} 21202$ ) for $24 \mathrm{~h}$ at $4^{\circ} \mathrm{C}$, washed again, and mounted with $2.5 \%$ DABCO in glycerol. Cells colocalizing FITC and TH in the dmArc were considered as TIDA neurons.

ISH. DAT-Cre-floxed-tdTomato mice were anesthetized with pentobarbital, killed by decapitation, and the brains were rapidly removed and frozen on dry ice; $10-\mu \mathrm{m}$-thick coronal sections were cut using a cryostat and thaw-mounted onto SuperFrost glass slides. Sections were fixed in $4 \%$ PFA for $15 \mathrm{~min}$ at $4^{\circ} \mathrm{C}$ and then dehydrated through incubation in $50 \% \mathrm{EtOH}(1 \times 5 \mathrm{~min}), 70 \% \mathrm{EtOH}(1 \times 5 \mathrm{~min})$, and last $100 \% \mathrm{EtOH}$ $(2 \times 5 \mathrm{~min})$. Slides were air-dried for $10 \mathrm{~min}$, and a hydrophobic barrier was created around each section using the ImmEdge pen (Vector Laboratories). ISH was performed using a modification of the RNAScope (Advanced Cell Diagnostics) protocol. Pretreat 4 (ACDBio, RNAscope Fluorescent Multiplex Reagent Kit, 320850) was added to entirely cover the sections for $30 \mathrm{~min}$ at room temperature. After PBS washing, sections were incubated with Mm-Th-C3 (317621-C3), Mm-Slc6a3-C2 (315441C2), and tdTomato (317041) RNAscope probes for $2 \mathrm{~h}$ at $40^{\circ} \mathrm{C}$ using the HybEZ Humidifying System (ACDBio). The following incubation steps were then performed: Amp 1-FL for $30 \mathrm{~min}$ at $40^{\circ} \mathrm{C}$, Amp 2-FL for $15 \mathrm{~min}$ at $40^{\circ} \mathrm{C}$, Amp 3-FL for $30 \mathrm{~min}$ at $40^{\circ} \mathrm{C}$, and Amp 4-FL-AltB for $15 \mathrm{~min}$ at $40^{\circ} \mathrm{C}$ (320850). Wash buffer (320850) was used to rinse the slides after each step. Sections were incubated with DAPI solution (320850) for $30 \mathrm{~s}$ at room temperature, and ProLong Gold Antifade Mountant (Thermo Fisher Scientific) was added before placing the coverslips. Quantification of mRNA coexistence within cells was performed on confocal $Z$-stack $\mathrm{dm}$ Arc images acquired at $40 \times$ magnification.

Confocal microscopy. Brain slices were imaged by epifluorescence microscopy (Carl Zeiss, Imager M1) or confocal microscopy (Carl Zeiss, LSM 800) for subsequent analysis. Brain areas were determined according to their anatomy using Paxinos and Franklin brain atlas (Franklin and Paxinos, 2008).

Carbon fiber microelectrodes. Carbon fiber electrodes were fabricated by aspirating $7-\mu \mathrm{m}$-diameter carbon fibers (Cytec Engineered Materials) into borosilicate glass capillaries (1.2 mm O.D., $0.69 \mathrm{~mm}$ I.D., Sutter
Instrument). The capillaries were subsequently pulled with a commercial micropipette puller (Sutter Instrument, P-97) and sealed with epoxy (EpoTek 301, Epoxy Technology). The electrode tips were polished at a $45^{\circ}$ angle on a diamond dust-embedded micropipette-beveling wheel (model BV-10, Sutter Instrument). Electrodes were tested in solutions of known concentrations of dopamine. Only electrodes showing reaction kinetics typical of dopamine (as examined in current vs time plots, and current vs voltage plots) were used.

FSCV. A Chem-Clamp potentiostat (Dagan) and two data acquisition boards (PCI-6221, National Instruments) run by the TH 1.0 CV program (ESA) were used to collect all electrochemical data. Cyclic voltammograms were obtained by applying a triangular waveform potential $(-0.4$ to $1.3 \mathrm{~V} \mathrm{vs} \mathrm{Ag} / \mathrm{AgCl}$ ) repeated every $100 \mathrm{~ms}$ at a scan rate of $200 \mathrm{~V} / \mathrm{s}$ (low pass Bessel filter at $3 \mathrm{kHz}$ ). Each cyclic voltammogram was a background-subtracted average of 10 successive cyclic voltammograms taken at the maximum oxidation peak current. All electrodes were allowed to cycle for at least $15 \mathrm{~min}$ before recording to stabilize the background current. The recorded current response was converted to dopamine concentration via in vitro electrode calibration in a standard dopamine solution after each experiment. Acquired data were analyzed and plotted using MATLAB routines, and statistical analysis was performed using Prism 6.0 (GraphPad). Last, bath application of the DAT blocker methylphenidate in isolation (i.e., in the absence of a brain slice) did not generate oxidative current during FSCV recordings $(n=3)$. Methylphenidate hydrochloride (M2892, Sigma-Aldrich) was dissolved in aCSF and was bath applied via gravitational flow. TTX was purchased from Alomone Labs (CAS \#18660-81-6) and dissolved in deionized $\mathrm{H}_{2} \mathrm{O}$. 4-AP (275875) and cadmium chloride $\left(\mathrm{CdCl}_{2}, 275875\right)$ were purchased from Sigma-Aldrich, and were dissolved in deionized $\mathrm{H}_{2} \mathrm{O}$.

Extracellular stimulation. Electrical stimulation of the external zone of the lateral ME was performed with borosilicate glass microcapillaries (same as used for patch recordings), connected to a stimulus isolation unit (MI401; Zoological Institute, University of Cologne, Cologne, Germany). The stimulation intensity was set to $2 \times$ the minimal stimulus intensity required to reliably evoke dopamine release events using a stimulation protocol of $3 \mathrm{~s}, 10 \mathrm{~Hz}$, and $5 \mathrm{~ms}$ pulse width and typically scaled between 10 and $100 \mathrm{~mA}$ in amplitude. Only WT C57BL/6J mice were used on FSCV recordings with electrically evoked dopamine release.

Experimental design and statistical analysis. Immunohistochemistry and in situ data were collected from a minimum of 8 animals, each animal contributing a single or two sections per dataset. Electrophysiology data were collected from 10 animals, each animal contributing four or five cells in the dataset. FSCV data were collected from multiple brain slices collected from a minimum of 3 individual animals on consequent experimental days. A minimum of five recordings represent each FSCV data group. All $t$ tests and one-way ANOVAs were performed using Prism software (GraphPad). The appropriate post hoc test was used for each one-way ANOVA. Normality was determined by D'Agostino-Pearson normality test. Statistical significance was set at $p<0.05$.

\section{Results}

\section{Absence of detectable spontaneous dopamine release in coronal hypothalamic slices}

TIDA neurons (Fig. $1 A$ ) were targeted for recording using DATtdTomato mice (Fig. $1 B-D$ ). To evaluate the coexpression between TH and DAT, and the DAT-Cre mouse line as an appropriate model for identifying TIDA cells, we performed triple-label ISH for TH, DAT, and tdTomato in hypothalamic brain sections from DAT-tdTomato mice (Fig. $1 E$ ). The majority (84\%) of cells expressed all three mRNA species, suggesting that the DAT-Cre line offers a suitable model for investigation of TIDA neuron physiology (i.e., dopaminergic neurons in the dmArc; Fig. $1 F)$.

Whole-cell patch-clamp recordings confirmed that mouse TIDA neurons exhibit a diverse range of firing rates in vitro in agreement with earlier reports (Romanò et al., 2013; X. Zhang and van den Pol, 
A

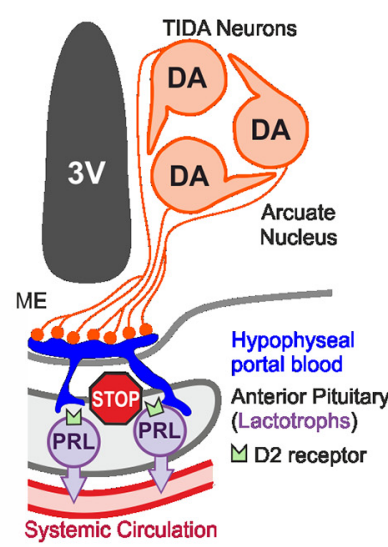

G

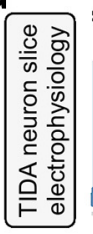

suprathreshold oscillating

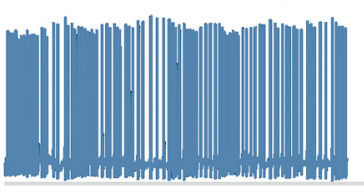

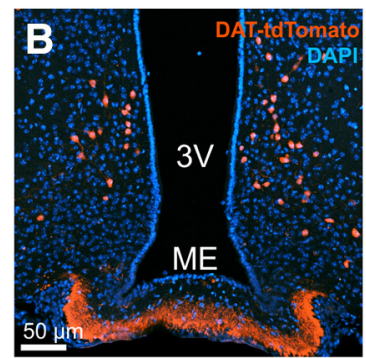

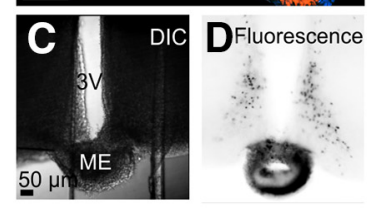

subthreshold oscillating

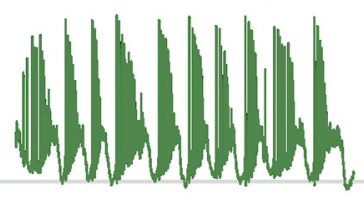

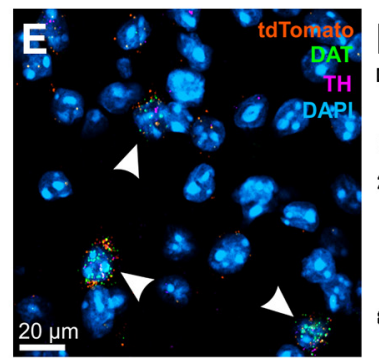

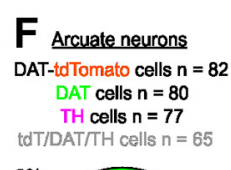

2\%
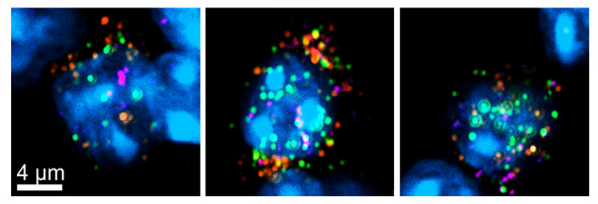

quiescent

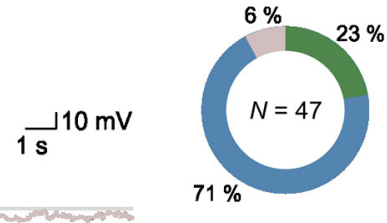

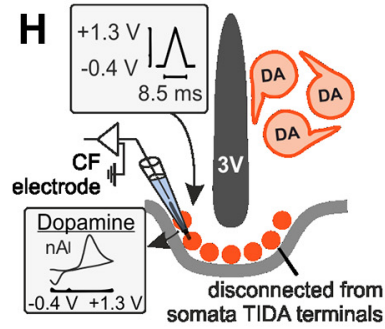

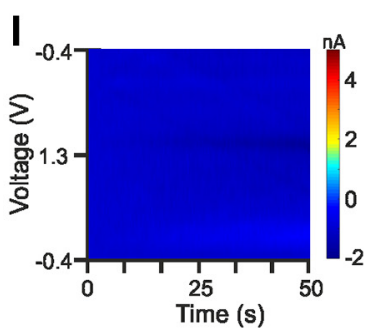

$\mathbf{J}$

K
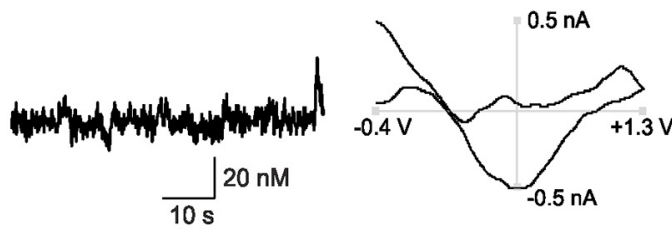

Figure 1. TIDA neuron preparation and absence of detectable spontaneous dopamine release in the ME in acute hypothalamic slices. $A$, Schematic illustration of the lactotropic axis and the TIDA neuron projection to the ME. $\boldsymbol{B}-\boldsymbol{D}$, DAT promoter-driven expression of tdTomato for the identification of TIDA cells after fixation $(\boldsymbol{B})$ and in acute brain slices used for electrophysiology visualized in differential interference contrast (DIC) ( $($ ), and in fluorescence ( $\boldsymbol{D}$, converted to black and white and inverted) illumination, respectively. $\boldsymbol{E}$, ISH for the TH, DAT, and tdTomato mRNA to quantify TH-, DAT-, and Cre-mediated expression of floxed constructs in the DAT-Cre mouse line (top). High magnification of three cells indicated via white arrows in $\boldsymbol{E}$ (bottom). $\boldsymbol{F}$, Quantification of TH, DAT, and tdTomato mRNA coexistence in cell bodies reveals an $84 \%$ colocalization between the three transcripts $(N=16$ confocal images collected from $N=8$ arcuate containing sections [ $-1.8 \mathrm{~mm}$ from bregma] from 8 mice). G, Mouse TIDA neurons exhibit various patterns of activity, suprathreshold oscillations (left), subthreshold oscillations (middle), and quiescent behavior (right). Quantification of the proportion of TIDA neurons exhibiting the different forms of activity presented in the far right. $\boldsymbol{H}$, Schematic drawing illustrating the use of FSCV and carbon fiber (CF) disc electrodes to measure TIDA neural activity with neurotransmitter (dopamine) release in the ME. $\boldsymbol{I}-\boldsymbol{K}$, Representative color plot $(\boldsymbol{I})$, current versus time plot $(\boldsymbol{K})$, and voltammogram $(\boldsymbol{J})$ generated through voltammetric measurements revealing no spontaneous dopamine release above detection threshold ( $5-10 \mathrm{~nm})$ in the $\mathrm{ME}(N=20$ recordings from $N=10$ slices from $N=5$ mice). $3 \mathrm{~V}$, Third ventricle.

2015; Stagkourakis et al., 2018) (Figure 1G). The majority (71\%) of TIDA cells were found to have a tonic firing pattern with phasic alterations in firing frequency, echoed in phasic fluctuations in membrane voltage (Fig. 1G, middle). Approximately one-fourth of the cells exhibited oscillatory, rhythmic firing interspersed with brief ( $\sim 500 \mathrm{~ms}$ ) periods of quiescence (Fig. $1 G$, left). A small fraction of the TIDA neurons in the slice preparation were consistently hyperpolarized and quiescent (Fig. $1 G$, right).

As TIDA neurons are spontaneously active in vitro, we first asked whether baseline dopamine release can be detected at the site of the terminals in the slice preparation. Carbon fiber electrodes were thus placed in the ME, and an adapted FSCV protocol from Kosillo et al. (2016) was applied (Fig. 1H). In this configuration, no dopamine signal could be observed above the detection threshold $(\sim 10 \mathrm{~nm} ; N=20$ recordings from $N=10$ slices from $N=5$ mice; Fig. $1 I-K)$. One possible reason for this failure to detect dopamine may be that the axons connecting the TIDA cell somata in the dmArc and the terminals in the ME are largely severed in the coronal slice preparation, as indicated by cytoarchitectonic studies (van den Pol and Cassidy, 1982), interrupting impulse traffic. Similar observations have occurred in other dopamine systems, such as in the striatum (Threlfell et al., 2012;
O’Neill et al., 2017) and nucleus accumbens (Melchior and Jones, 2017), where the absence of spontaneous dopamine release in slice preparations has motivated electrically or optically evoked investigations of dopamine release dynamics at different conditions. We therefore next sought to identify evoked dopamine release properties via optogenetic stimulation of the TIDA terminals. This strategy offers the benefit that the dynamics of the transmitter release at the level of the terminals, on the one hand, and at the somatodendritic level on the other, can be studied separately.

\section{Stable electrically and optically evoked dopamine release in the ME}

To enable dopamine release from the terminals, we first used extracellular electrical stimulation of the lateral part of the ME during voltammetric recordings using brain slices from C57 WT mice (Fig. 2A). Electrical stimulation of the ME led to reliable, stable dopamine release over time when tested with 5 min sampling interval (Fig. $2 B, E ; N=5, F_{(2.258,9.034)}=0.3811, \mathrm{df}=6, p=$ 0.7171 , repeated-measures one-way ANOVA; Table 1 ). Next, to study optogenetically evoked dopamine release, DAT-Cre animals were bilaterally injected in the dmArc with AAV-DIOChR2-eYFP-hGH. One month later, FSCV recordings were 
A Electrically or optically induced dopamine release

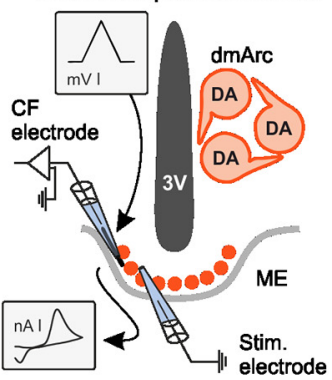

- Electrical stimulation

- Optical stimulation

Stim.: $5 \mathrm{~s}, 10 \mathrm{~Hz}, 5 \mathrm{~ms}$

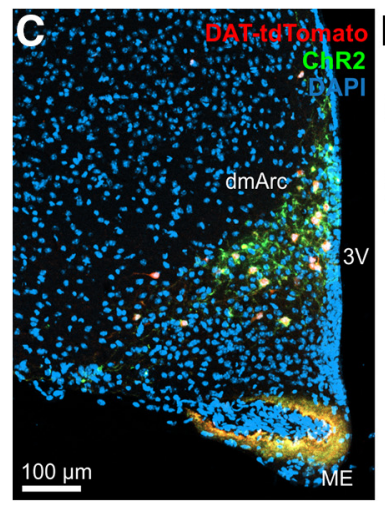

B
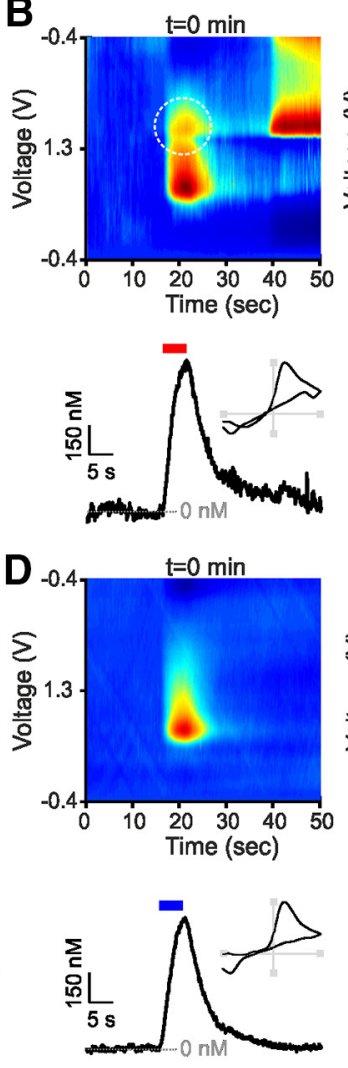

G

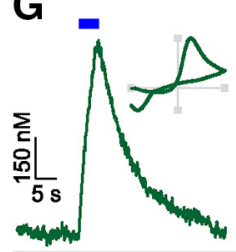

Control

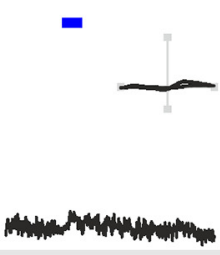

TTX

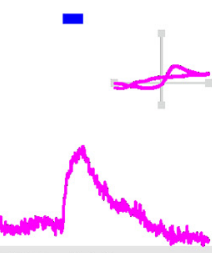

TTX + 4-AP
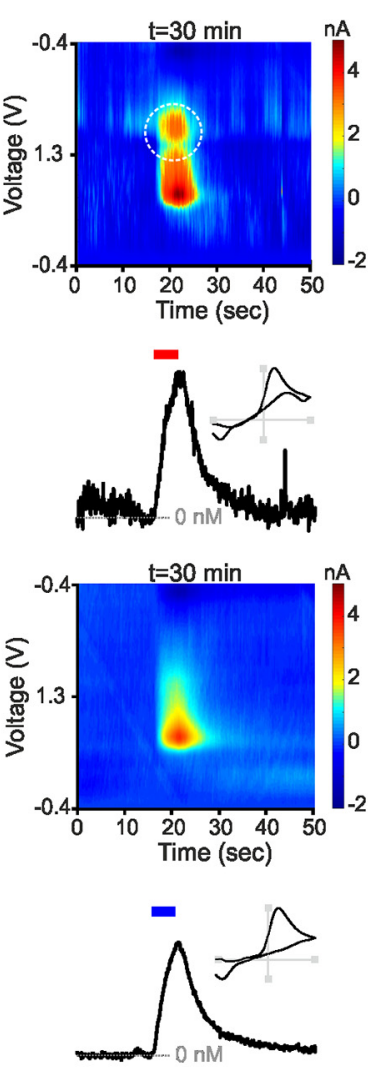

H

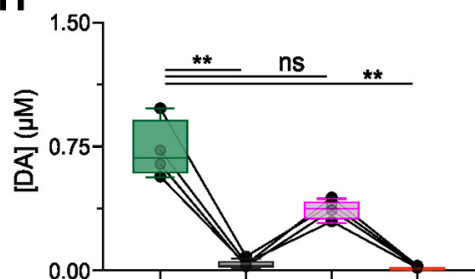

Figure 2. Evoked dopamine release in the ME is stable over time. $\boldsymbol{A}$, Schematic drawing illustrating the use of FSCV with electrically and optically evoked dopamine release in the ME. $\boldsymbol{B}$, Electrically evoked dopamine release at $t=0 \mathrm{~min}$ and $30 \mathrm{~min}$ after, in arcuate slices from WT C57BL/6J mice (dashed circle line/peak represents the electrical stimulation artifact or another oxidizing substance released in the ME following the stimulus). C, Confocal Z-stack micrograph illustrating virally mediated ChR2-eYFP expression in the dmArc in the DAT-tdTomato mouse. The ChR2-eYFP and DAT-tdTomato fluorescence in the ME. D, Optogenetically evoked dopamine release at $t=0$ min and 30 min later, in arcuate slices from DAT-Cre mice of C57BL/6J background. $E$, Both electrically (red) and optically evoked (blue) dopamine release with a 5 min stimulation interval is sustainable over time ( $N=5-7$ per group, repeated-measures one-way ANOVA, $p>0.05$; Table 1$)$. $\boldsymbol{F}$, Evoked dopamine release with a 1 min stimulation interval leads to a reversible dopamine depletion, reversible upon return to a 5 min stimulation interval $(N=5$ per group, repeated-measures one-way ANOVA, $p<0.0001)$. G, Representative FSCV traces with ChR2-evoked dopamine release in control conditions: versus in the presence of the Na ${ }^{+}$channel blocker TTX, versus coapplication of TTX and the $\mathrm{K}^{+}$channel blocker 4-AP, and versus coapplication of TTX+4-AP and the nonselective $\mathrm{Ca}^{2+}$ channel blocker $\mathrm{CdCl}_{2} . \mathbf{H}, \mathbf{Q u a n t i f i c a t i o n}$ of dopamine release in different conditions illustrated in $\boldsymbol{G}$ (repeated-measures one-way ANOVA, $p=0.0032$; Table 1). ${ }^{* *} p<0.01$. Data are mean \pm SEM. 3V, Third ventricle.

performed in vitro to test for optically evoked dopamine release (Fig. $2 A, C$ ). Using a stimulation protocol of $5 \mathrm{~s}$ in duration and $10 \mathrm{~Hz}$ frequency stimulation with $5 \mathrm{~ms}$ pulse width, robust and stable dopamine release was recorded from the ME (Fig. $2 D, E$ ) similarly to what was observed with electrically evoked dopamine measurements. To test for the possibility of dopamine depletion at the terminals with repeated stimulation, we performed recurrent photostimulation at different time intervals ( 1 or $5 \mathrm{~min}$ ). Photostimulation with 5 min interval resulted in stable evoked release at near $100 \%$ of the initial levels, throughout a $30 \mathrm{~min}$ period (Fig. $2 E ; N=7, F_{(3.161,18.96)}=0.2747$, $\mathrm{df}=6, p=0.8522$, repeated-measures one-way ANOVA; Table 1), whereas photostimulation with $1 \mathrm{~min}$ intervals resulted in attenuation of the dopamine signal to near $50 \%$ of the basal levels over $10 \mathrm{~min}$ (Fig. $2 F ; N=5, F_{(3.036,12.14)}=2.188, \mathrm{df}=14, p=0.1413$, repeatedmeasures one-way ANOVA; Table 1). Once the longer (5 min) photostimulation interval was reinstated, however, the dopamine signal recovered to initial levels (Fig. $2 F$ ). Previous work has suggested that AAVs containing the hGH minigene can potentially alter excitability of transduced endocrine cells (Brouwers et al., 2014). Because the viral constructs used in the present study contain the hGH minigene, control experiments were performed to address whether this construct might influence TIDA behavior. However, quantification of firing rates and PSTAT5 immunoreactivity (as a marker of prolactin receptor activation via hGH) (Goffin and Kelly, 1997; Buteau et al., 1998) in C57 WT, DAT-tdTomato, and DAT-Cre mice injected with AAV-DIOeYFP-hGH did not yield any changes related to hGH expression (Fig. 3A-D; Table 1).

Importantly, optically evoked dopamine release was found to be sensitive to application of TTX (500 nM), whereas coapplication of TTX $(500 \mathrm{nM})$ and 4-AP $(100 \mu \mathrm{M})$ led to partial recovery 


\section{Table 1. Statistics}

\begin{tabular}{|c|c|c|c|c|c|c|c|c|}
\hline Figures & Test & $N$ & Fort & $\mathrm{df}$ & $p$ & Multiple comparisons & Adjusted $p$ & $p$ summary \\
\hline \multirow{6}{*}{$\begin{array}{l}\text { Figure } 2 E \text { (electrical } \\
\text { stimulation; in } \\
\text { red) }\end{array}$} & \multirow{6}{*}{$\begin{array}{l}\text { Repeated-measures one-way ANOVA } \\
\text { with Dunnett's multiple compari- } \\
\text { sons test }\end{array}$} & \multirow[t]{6}{*}{5} & \multirow{6}{*}{$F_{(2.258,9.034)}=0.3811$} & \multirow[t]{6}{*}{6} & \multirow[t]{6}{*}{0.7171} & 0 min versus $5 \mathrm{~min}$ & 0.8652 & NS \\
\hline & & & & & & 0 min versus $10 \mathrm{~min}$ & $>0.9999$ & NS \\
\hline & & & & & & 0 min versus $15 \mathrm{~min}$ & 0.9961 & NS \\
\hline & & & & & & 0 min versus $20 \mathrm{~min}$ & 0.9891 & NS \\
\hline & & & & & & 0 min versus $25 \mathrm{~min}$ & 0.2479 & NS \\
\hline & & & & & & 0 min versus $30 \mathrm{~min}$ & 0.5699 & NS \\
\hline \multirow{6}{*}{$\begin{array}{l}\text { Figure } 2 E \text { (optical } \\
\text { stimulation; in } \\
\text { blue) }\end{array}$} & \multirow{6}{*}{$\begin{array}{l}\text { Repeated-measures one-way ANOVA } \\
\text { with Dunnett's multiple compari- } \\
\text { sons test }\end{array}$} & \multirow[t]{6}{*}{7} & \multirow{6}{*}{$F_{(3.161,18.96)}=0.2747$} & \multirow[t]{6}{*}{6} & \multirow[t]{6}{*}{0.8522} & 0 min versus $5 \mathrm{~min}$ & 0.5051 & NS \\
\hline & & & & & & 0 min versus $10 \mathrm{~min}$ & 0.9983 & NS \\
\hline & & & & & & 0 min versus $15 \mathrm{~min}$ & 0.8838 & NS \\
\hline & & & & & & 0 min versus $20 \mathrm{~min}$ & 0.9983 & NS \\
\hline & & & & & & 0 min versus $25 \mathrm{~min}$ & 0.9960 & NS \\
\hline & & & & & & 0 min versus $30 \mathrm{~min}$ & 0.9968 & NS \\
\hline \multirow[t]{14}{*}{ Figure $2 F$} & \multirow{14}{*}{$\begin{array}{l}\text { Repeated-measures one-way ANOVA } \\
\text { with Dunnett's multiple compari- } \\
\text { sons test }\end{array}$} & \multirow[t]{14}{*}{5} & $F_{(3.036,12.14)}=2.188$ & 14 & 0.1413 & 0 min versus $1 \mathrm{~min}$ & $>0.9999$ & NS \\
\hline & & & & & & 0 min versus 2 min & 0.7617 & NS \\
\hline & & & & & & 0 min versus $3 \mathrm{~min}$ & 0.9999 & NS \\
\hline & & & & & & 0 min versus $4 \mathrm{~min}$ & 0.9156 & NS \\
\hline & & & & & & 0 min versus $5 \mathrm{~min}$ & 0.9098 & NS \\
\hline & & & & & & 0 min versus $6 \mathrm{~min}$ & 0.3838 & NS \\
\hline & & & & & & 0 min versus $7 \mathrm{~min}$ & 0.0835 & NS \\
\hline & & & & & & $0 \mathrm{~min}$ versus $8 \mathrm{~min}$ & 0.0256 & * \\
\hline & & & & & & 0 min versus 9 min & 0.0218 & * \\
\hline & & & & & & 0 min versus $10 \mathrm{~min}$ & 0.2914 & NS \\
\hline & & & & & & 0 min versus 15 min & 0.9977 & NS \\
\hline & & & & & & 0 min versus $20 \mathrm{~min}$ & 0.9725 & NS \\
\hline & & & & & & 0 min versus $25 \mathrm{~min}$ & 0.9941 & NS \\
\hline & & & & & & 0 min versus $30 \mathrm{~min}$ & 0.8931 & NS \\
\hline Figure $2 H(10 \mathrm{~ms}$ & one-way ANOVA with Dunnett's & 4 & $F_{(3,9)}=1.282$ & 3 & 0.0032 & Control versus TTX & 0.0068 & $* *$ \\
\hline pulse duration) & multiple comparisons test & & & & & Control versus TTX + 4-AP & 0.0757 & NS \\
\hline & & & & & & $\begin{array}{l}\text { Control versus TTX }+4-\mathrm{AP}+ \\
\mathrm{CdCl}_{2}\end{array}$ & 0.0092 & $* *$ \\
\hline Figure $3 B$ & $\begin{array}{l}\text { one-way ANOVA with Dunnett's } \\
\text { multiple comparisons test }\end{array}$ & $8-12$ & $F_{(2,25)}=0.1192$ & 2 & 0.8881 & $\begin{array}{l}\text { C57 wt - TH versus DAT-tdTo- } \\
\text { mato }\end{array}$ & 0.9889 & NS \\
\hline & & & & & & C57 wt - TH versus DAT-eYFP & 0.9050 & NS \\
\hline & & & & & & $\begin{array}{l}\text { C57 wt-TH + pSTAT5 versus } \\
\text { DAT-tdTomato + pSTAT5 }\end{array}$ & 0.8697 & NS \\
\hline & & & & & & $\begin{array}{l}\text { C57 wt-TH + pSTAT5 versus } \\
\text { DAT-eYFP + pSTAT5 }\end{array}$ & 0.7708 & NS \\
\hline Figure $3 D$ & One-way ANOVA with Dunnett's & $10-33$ & $F_{(2,52)}=0.3014$ & 2 & 0.7411 & DAT-tdTomato versus C57 & 0.9312 & NS \\
\hline & multiple comparisons test & & & & & DAT-tdTomato versus DAT-eYFP & 0.6881 & NS \\
\hline Figure 4D & Two-tailed paired $t$ test & 6 & 4.357 & 5 & 0.0073 & $* *$ & & \\
\hline Figure $4 B$ & Ordinary one-way ANOVA with & 33 & $F_{(14,338)}=17.08$ & 14 & $<0.0001$ & 1st versus 4th AP & $<0.0001$ & $* * * *$ \\
\hline & Tukey's multiple comparisons test & & & & & 2nd versus 4th AP & $<0.0001$ & $* * * *$ \\
\hline & & & & & & 5 th versus 10 th $\mathrm{AP}$ & $>0.9999$ & NS \\
\hline & & & & & & 10th versus 14 th $A P$ & 0.0132 & * \\
\hline & & & & & & 10th versus 15 th $A P$ & 0.0117 & * \\
\hline Figure $4 F(2 \mathrm{~ms}$ & Repeated-measures one-way ANOVA & 6 & $F_{(1.935,9.677)}=100.6$ & 6 & $<0.0001$ & $2 \mathrm{~Hz}$ versus $5 \mathrm{~Hz}$ & $>0.9999$ & NS \\
\hline pulse duration, & with Dunnett's multiple compari- & & & & & $2 \mathrm{~Hz}$ versus $10 \mathrm{~Hz}$ & 0.0364 & * \\
\hline optical stimula- & sons test & & & & & $2 \mathrm{~Hz}$ versus $20 \mathrm{~Hz}$ & $<0.0001$ & $* * * *$ \\
\hline tion) & & & & & & $2 \mathrm{~Hz}$ versus $30 \mathrm{~Hz}$ & 0.0001 & $* * *$ \\
\hline & & & & & & $2 \mathrm{~Hz}$ versus $40 \mathrm{~Hz}$ & $<0.0001$ & $* * * *$ \\
\hline & & & & & & $2 \mathrm{~Hz}$ versus $50 \mathrm{~Hz}$ & $<0.0001$ & $* * * *$ \\
\hline Figure $4 F(5 \mathrm{~ms}$ & & 5 & $F_{(6,24)}=100.4$ & 6 & $<0.0001$ & $2 \mathrm{~Hz}$ versus $5 \mathrm{~Hz}$ & $>0.9999$ & NS \\
\hline pulse duration, & & & & & & $2 \mathrm{~Hz}$ versus $10 \mathrm{~Hz}$ & 0.9932 & NS \\
\hline optical stimula- & & & & & & $2 \mathrm{~Hz}$ versus $20 \mathrm{~Hz}$ & $<0.0001$ & $* * * *$ \\
\hline tion) & & & & & & $2 \mathrm{~Hz}$ versus $30 \mathrm{~Hz}$ & $<0.0001$ & $* * * *$ \\
\hline & & & & & & $2 \mathrm{~Hz}$ versus $40 \mathrm{~Hz}$ & $<0.0001$ & $* * * *$ \\
\hline & & & & & & $2 \mathrm{~Hz}$ versus $50 \mathrm{~Hz}$ & $<0.0001$ & $* * * *$ \\
\hline Figure $4 F(10 \mathrm{~ms}$ & & 4 & $F_{(1.503,4.508)}=72.97$ & 6 & 0.0004 & $2 \mathrm{~Hz}$ versus $5 \mathrm{~Hz}$ & $>0.9999$ & NS \\
\hline pulse duration, & & & & & & $2 \mathrm{~Hz}$ versus $10 \mathrm{~Hz}$ & $>0.9999$ & NS \\
\hline optical stimula- & & & & & & $2 \mathrm{~Hz}$ versus $20 \mathrm{~Hz}$ & 0.0595 & NS \\
\hline tion) & & & & & & $2 \mathrm{~Hz}$ versus $30 \mathrm{~Hz}$ & 0.007 & $* *$ \\
\hline & & & & & & $2 \mathrm{~Hz}$ versus $40 \mathrm{~Hz}$ & 0.0016 & $* *$ \\
\hline & & & & & & $2 \mathrm{~Hz}$ versus $50 \mathrm{~Hz}$ & 0.0005 & $* * *$ \\
\hline
\end{tabular}


Table 1. Continued

\begin{tabular}{|c|c|c|c|c|c|c|c|c|}
\hline Figures & Test & $N$ & For $t$ & $\mathrm{df}$ & $p$ & Multiple comparisons & Adjusted $p$ & $p$ summary \\
\hline $\begin{array}{l}\text { Figure } 4 F \text { ( } 5 \text { ms } \\
\text { pulse duration, } \\
\text { electrical stimu- } \\
\text { lation) }\end{array}$ & $\begin{array}{l}\text { Repeated-measures one-way ANOVA } \\
\text { with Dunnett's multiple compari- } \\
\text { sons test }\end{array}$ & 9 & $F_{(1.135,10.68)}=86.62$ & 8 & $<0.0001$ & $\begin{array}{l}2 \mathrm{~Hz} \text { versus } 5 \mathrm{~Hz} \\
2 \mathrm{~Hz} \text { versus } 10 \mathrm{~Hz} \\
2 \mathrm{~Hz} \text { versus } 20 \mathrm{~Hz} \\
2 \mathrm{~Hz} \text { versus } 30 \mathrm{~Hz} \\
2 \mathrm{~Hz} \text { versus } 40 \mathrm{~Hz} \\
2 \mathrm{~Hz} \text { versus } 50 \mathrm{~Hz}\end{array}$ & $\begin{array}{l}>0.9999 \\
>0.9999 \\
<0.0001 \\
<0.0001 \\
<0.0001 \\
<0.0001\end{array}$ & $\begin{array}{l}\text { NS } \\
\text { NS } \\
* * * * \\
* * * * \\
* * * * \\
* * * *\end{array}$ \\
\hline $\begin{array}{l}\text { Figure } 4 \mathrm{H} \text { ( } 2 \mathrm{~ms} \\
\text { pulse duration, } \\
\text { optical stimula- } \\
\text { tion) }\end{array}$ & $\begin{array}{l}\text { Repeated-measures one-way ANOVA } \\
\text { with Dunnett's multiple compari- } \\
\text { sons test }\end{array}$ & 6 & $F_{(1.111,8.889)}=4.124$ & 5 & 0.0706 & $\begin{array}{l}2 \mathrm{~Hz} \text { versus } 5 \mathrm{~Hz} \\
2 \mathrm{~Hz} \text { versus } 10 \mathrm{~Hz} \\
2 \mathrm{~Hz} \text { versus } 20 \mathrm{~Hz} \\
2 \mathrm{~Hz} \text { versus } 30 \mathrm{~Hz} \\
2 \mathrm{~Hz} \text { versus } 40 \mathrm{~Hz} \\
2 \mathrm{~Hz} \text { versus } 50 \mathrm{~Hz}\end{array}$ & $\begin{array}{l}0.268 \\
0.3002 \\
0.2444 \\
0.2637 \\
0.7629 \\
0.4558\end{array}$ & $\begin{array}{l}\text { NS } \\
\text { NS } \\
\text { NS } \\
\text { NS } \\
\text { NS } \\
\text { NS }\end{array}$ \\
\hline $\begin{array}{l}\text { Figure } 4 \mathrm{H} \text { ( } 5 \mathrm{~ms} \\
\text { pulse duration, } \\
\text { optical stimula- } \\
\text { tion) }\end{array}$ & & & $F_{(1.067,8.536)}=5.221$ & 5 & 0.0481 & $\begin{array}{l}2 \mathrm{~Hz} \text { versus } 5 \mathrm{~Hz} \\
2 \mathrm{~Hz} \text { versus } 10 \mathrm{~Hz} \\
2 \mathrm{~Hz} \text { versus } 20 \mathrm{~Hz} \\
2 \mathrm{~Hz} \text { versus } 30 \mathrm{~Hz} \\
2 \mathrm{~Hz} \text { versus } 40 \mathrm{~Hz} \\
2 \mathrm{~Hz} \text { versus } 50 \mathrm{~Hz}\end{array}$ & $\begin{array}{l}0.1586 \\
0.0442 \\
0.0852 \\
0.8233 \\
0.5971 \\
0.4555\end{array}$ & $\begin{array}{l}\text { NS } \\
* \\
\text { NS } \\
\text { NS } \\
\text { NS } \\
\text { NS }\end{array}$ \\
\hline $\begin{array}{l}\text { Figure } 4 H \text { ( } 5 \text { ms } \\
\text { pulse duration, } \\
\text { electrical stimu- } \\
\text { lation, electrical } \\
\text { stimulation) }\end{array}$ & $\begin{array}{l}\text { Repeated-measures one-way ANOVA } \\
\text { with Dunnett's multiple compari- } \\
\text { sons test }\end{array}$ & 5 & $F_{(1.816,7.265)}=18.98$ & 4 & 0.0015 & $\begin{array}{l}2 \mathrm{~Hz} \text { versus } 5 \mathrm{~Hz} \\
2 \mathrm{~Hz} \text { versus } 10 \mathrm{~Hz} \\
2 \mathrm{~Hz} \text { versus } 20 \mathrm{~Hz} \\
2 \mathrm{~Hz} \text { versus } 30 \mathrm{~Hz} \\
2 \mathrm{~Hz} \text { versus } 40 \mathrm{~Hz} \\
2 \mathrm{~Hz} \text { versus } 50 \mathrm{~Hz}\end{array}$ & $\begin{array}{l}0.0907 \\
0.0108 \\
0.0710 \\
0.4024 \\
0.8639 \\
0.9965\end{array}$ & $\begin{array}{l}\text { NS } \\
* \\
\text { NS } \\
\text { NS } \\
\text { NS } \\
\text { NS }\end{array}$ \\
\hline Figure 5D & $\begin{array}{l}\text { Ordinary one-way ANOVA with } \\
\text { Tukey's multiple comparisons test }\end{array}$ & 5 & $F_{(6,28)}=5.92$ & 6 & 0.0004 & $\begin{array}{l}0.5 \mathrm{~Hz} \text { versus } 1 \mathrm{~Hz} \\
0.5 \mathrm{~Hz} \text { versus } 2 \mathrm{~Hz} \\
0.5 \mathrm{~Hz} \text { versus } 5 \mathrm{~Hz} \\
0.5 \mathrm{~Hz} \text { versus } 10 \mathrm{~Hz} \\
0.5 \mathrm{~Hz} \text { versus } 20 \mathrm{~Hz} \\
0.5 \mathrm{~Hz} \text { versus } 30 \mathrm{~Hz} \\
1 \mathrm{~Hz} \text { versus } 2 \mathrm{~Hz} \\
1 \mathrm{~Hz} \text { versus } 5 \mathrm{~Hz} \\
1 \mathrm{~Hz} \text { versus } 10 \mathrm{~Hz} \\
1 \mathrm{~Hz} \text { versus } 20 \mathrm{~Hz} \\
1 \mathrm{~Hz} \text { versus } 30 \mathrm{~Hz} \\
2 \mathrm{~Hz} \text { versus } 5 \mathrm{~Hz} \\
2 \mathrm{~Hz} \text { versus } 10 \mathrm{~Hz} \\
2 \mathrm{~Hz} \text { versus } 20 \mathrm{~Hz} \\
2 \mathrm{~Hz} \text { versus } 30 \mathrm{~Hz} \\
5 \mathrm{~Hz} \text { versus } 10 \mathrm{~Hz} \\
5 \mathrm{~Hz} \text { versus } 20 \mathrm{~Hz} \\
5 \mathrm{~Hz} \text { versus } 30 \mathrm{~Hz} \\
10 \mathrm{~Hz} \text { versus } 20 \mathrm{~Hz} \\
10 \mathrm{~Hz} \text { versus } 30 \mathrm{~Hz} \\
20 \mathrm{~Hz} \text { versus } 30 \mathrm{~Hz}\end{array}$ & $\begin{array}{c}0.9922 \\
0.4408 \\
0.0016 \\
0.9448 \\
>0.9999 \\
0.9973 \\
0.844 \\
0.0097 \\
0.9999 \\
0.9979 \\
0.8659 \\
0.1787 \\
0.9559 \\
0.5291 \\
0.177 \\
0.0219 \\
0.0024 \\
0.0004 \\
0.9734 \\
0.6909 \\
0.9907\end{array}$ & $\begin{array}{l}\text { NS } \\
\text { NS } \\
* * \\
\text { NS } \\
\text { NS } \\
\text { NS } \\
\text { NS } \\
* * \\
\text { NS } \\
\text { NS } \\
\text { NS } \\
\text { NS } \\
\text { NS } \\
\text { NS } \\
\text { NS } \\
* \\
* * \\
* * * \\
\text { NS } \\
\text { NS } \\
\text { NS }\end{array}$ \\
\hline & & & Kruskal-Wallis statistic & $p$ & & Multiple comparisons & Adjusted $p$ & $p$-summary \\
\hline Figure $5 E$ & One-way Kruskal-Wallis ANOVA & 7 & -22964 & $<0.0001$ & & $\begin{array}{l}0.5 \mathrm{~Hz} \text { versus } 1 \mathrm{~Hz} \\
0.5 \mathrm{~Hz} \text { versus } 2 \mathrm{~Hz} \\
0.5 \mathrm{~Hz} \text { versus } 5 \mathrm{~Hz} \\
0.5 \mathrm{~Hz} \text { versus } 10 \mathrm{~Hz} \\
0.5 \mathrm{~Hz} \text { versus } 20 \mathrm{~Hz} \\
0.5 \mathrm{~Hz} \text { versus } 30 \mathrm{~Hz} \\
1 \mathrm{~Hz} \text { versus } 2 \mathrm{~Hz} \\
1 \mathrm{~Hz} \text { versus } 5 \mathrm{~Hz} \\
1 \mathrm{~Hz} \text { versus } 10 \mathrm{~Hz} \\
1 \mathrm{~Hz} \text { versus } 20 \mathrm{~Hz} \\
1 \mathrm{~Hz} \text { versus } 30 \mathrm{~Hz}\end{array}$ & $\begin{array}{l}<0.0001 \\
<0.0001 \\
<0.0001 \\
<0.0001 \\
<0.0001 \\
<0.0001 \\
>0.9999 \\
<0.0001 \\
<0.0001 \\
<0.0001 \\
<0.0001\end{array}$ & $\begin{array}{l}* * * * \\
* * * * \\
* * * * \\
* * * * \\
* * * * \\
* * * * \\
\text { NS } \\
* * * * \\
* * * * \\
* * * * \\
* * * *\end{array}$ \\
\hline
\end{tabular}


Table 1. Continued

\begin{tabular}{|c|c|c|c|c|c|c|c|c|}
\hline Figures & Test & $N$ & Fort & $\mathrm{df}$ & $p$ & Multiple comparisons & Adjusted $p$ & $p$ summary \\
\hline & & & & & & $\begin{array}{r}2 \mathrm{Hzversus} 5 \mathrm{~Hz} \\
2 \mathrm{Hzversus} 10 \mathrm{~Hz} \\
2 \mathrm{Hzversus} 2 \mathrm{OHz} \\
2 \mathrm{Hzversus} 3 \mathrm{OHz} \\
5 \mathrm{Hzversus} 10 \mathrm{~Hz} \\
5 \mathrm{Hzversus} 2 \mathrm{OHz} \\
5 \mathrm{Hzversus} 3 \mathrm{OHz} \\
10 \mathrm{Hzversus} 2 \mathrm{OHz} \\
10 \mathrm{Hzversus} 30 \mathrm{~Hz} \\
20 \mathrm{Hzversus} 3 \mathrm{OHz}\end{array}$ & $\begin{array}{l}<0.0001 \\
<0.0001 \\
<0.0001 \\
<0.0001 \\
<0.0001 \\
<0.0001 \\
<0.0001 \\
<0.0001 \\
<0.0001 \\
<0.0001\end{array}$ & $\begin{array}{l}* * * * \\
* * * * \\
* * * * \\
* * * * \\
* * * * \\
* * * * \\
* * * * \\
* * * * \\
* * * * \\
* * * *\end{array}$ \\
\hline & & $\begin{array}{l}\text { No. of } \\
\text { pairs }\end{array}$ & $t$ & $d f$ & & & & \\
\hline Figure $6 B$ & Two-tailed paired $t$ test & 6 & 4.439 & 5 & 0.0068 & & & $* *$ \\
\hline Figure $6 C$ & Two-tailed paired $t$ test & 6 & 0.4974 & 5 & 0.6400 & & & NS \\
\hline Figure $6 D$ & Two-tailed paired $t$ test & 6 & 5.228 & 5 & 0.0034 & & & $* *$ \\
\hline Figure $6 E$ & Two-tailed paired $t$ test & 6 & 1.115 & 5 & 0.3154 & & & NS \\
\hline
\end{tabular}

${ }^{*} p<0.05 ; *{ }^{* *}<0.01 ;{ }^{* * *} p<0.001 ;{ }^{* * * *} p<0.0001$.
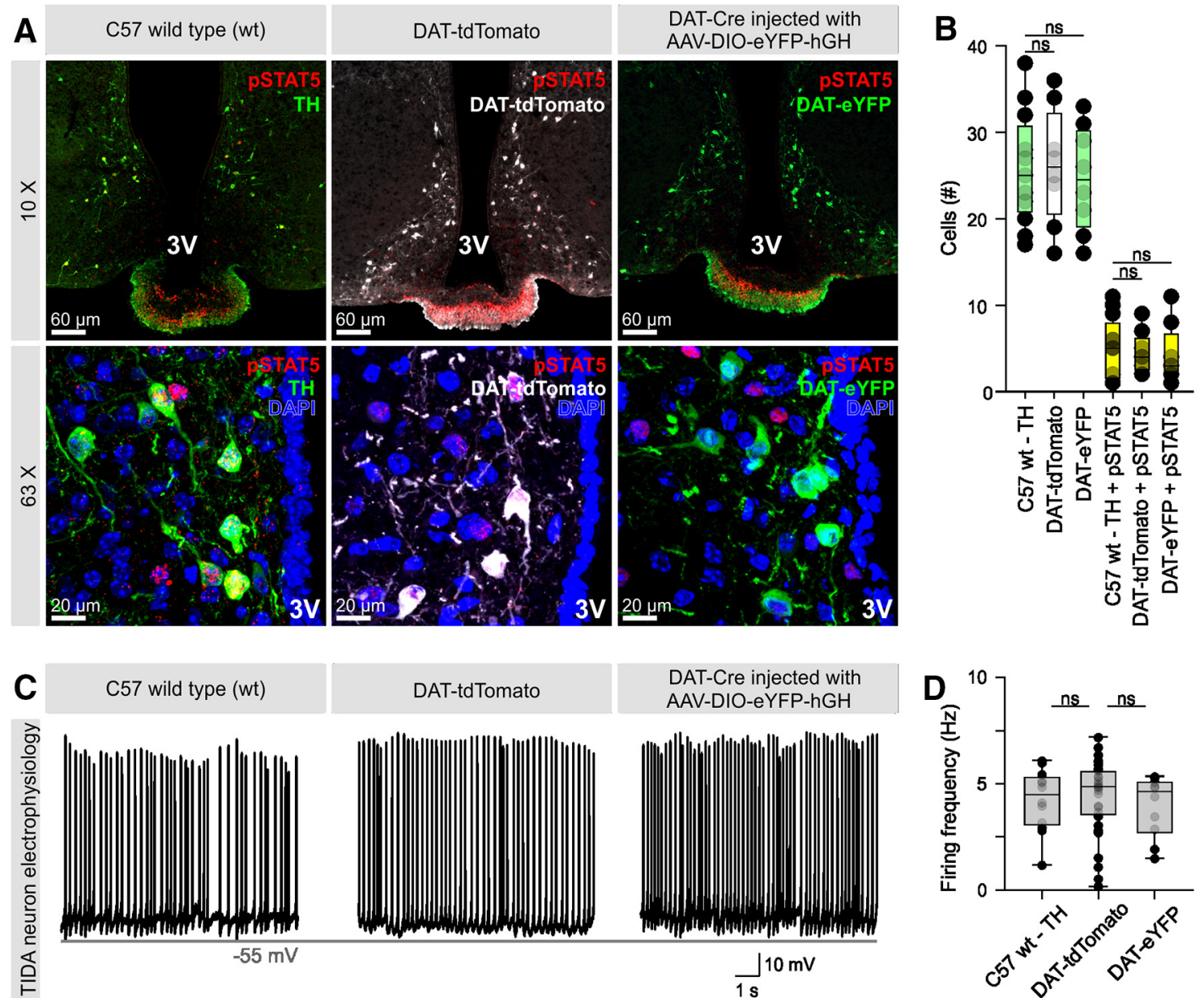

DAT-tdTomato

DAT-Cre injected with AAV-DIO-eYFP-hGH
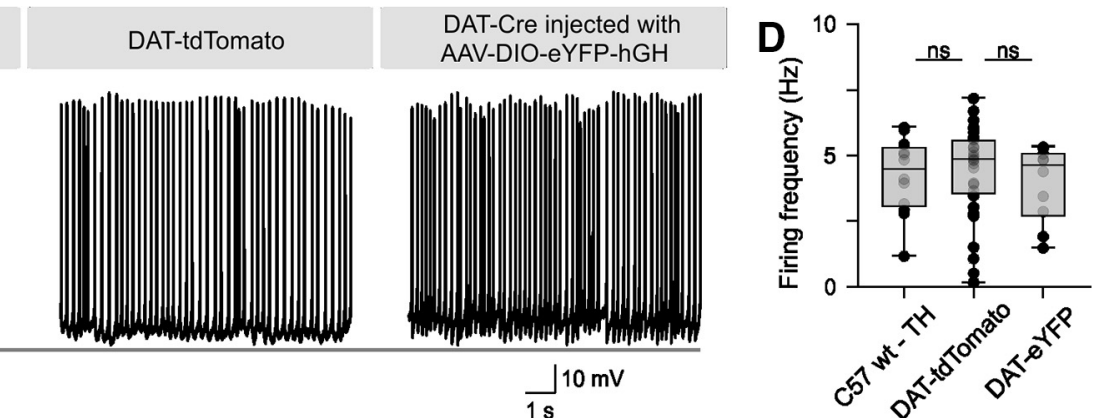

Figure 3. Expression of the $\mathrm{hGH}$ minigene does not impact on TIDA neuron excitability. A, pSTAT5 immunoreactivity illustrated via confocal Z-stack micrographs at low (10X) and high $(63 \times)$ magnification in the dmArc of (57 WT (wt), DAT-tdTomato, and DAT-Cre mice injected with an hGH minigene-containing viral construct. $B$, Quantification of dopamine neurons per hemisphere/section (box plots in green and white, $N=8-12$ per group, one-way ANOVA, $p=0.8881$; Table 1), and dopamine neurons colocalizing with $p S T A T 5$ (box plots in yellow, $N=8-12$ per group, one-way ANOVA, $p=0.8059$; Table 1). C, Representative traces of TIDA neuron firing patterns collected from (57 wt, DAT-tdTomato, and DAT-eYFP mice. $\boldsymbol{D}$, Quantification of TIDA neuron firing frequency, recorded from the different mouse lines $(N=10-33$ per group, one-way ANOVA, $p=0.7411 ;$ Table 1$)$. Data are mean \pm SEM. 3V, Third ventricle. 
A I-clamp - whole-cell

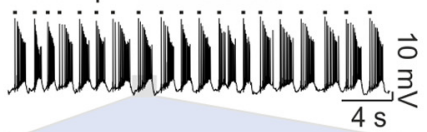

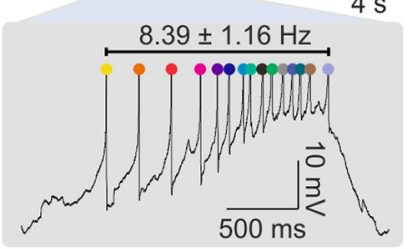

D V-clamp - whole-cell

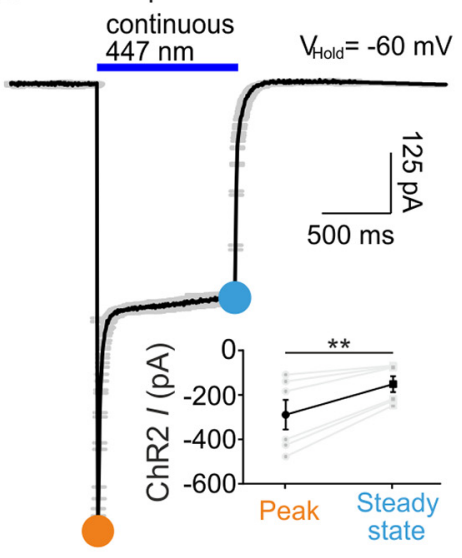

B

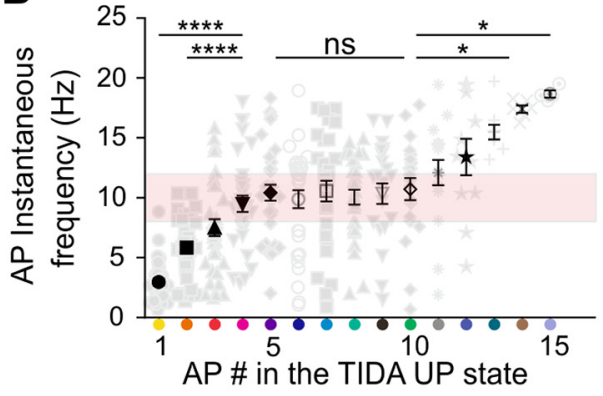

E I-clamp - whole-cell

Electrical stimulation ChR2 stimulation

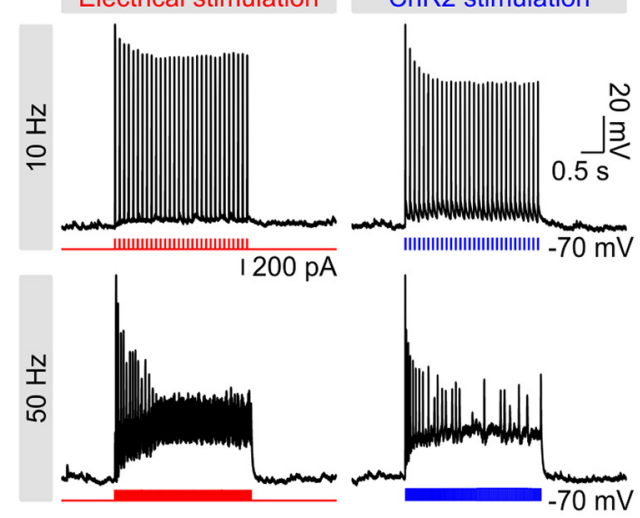

C

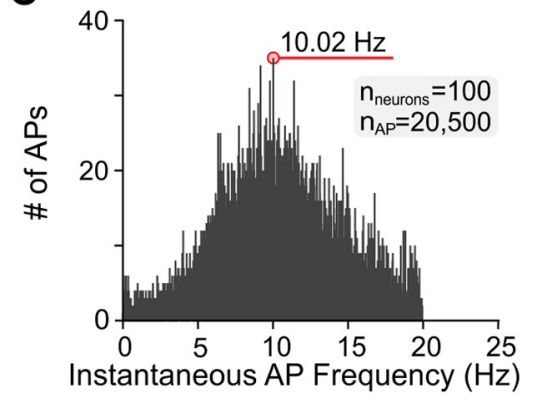

$\mathbf{G}$
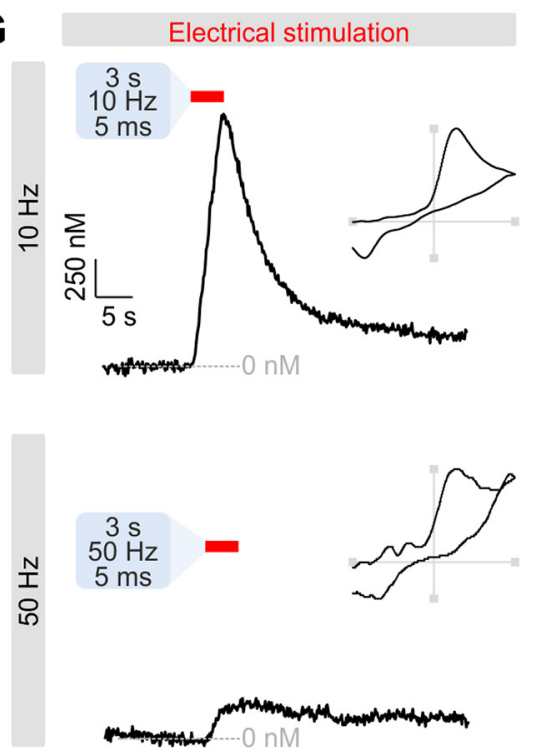
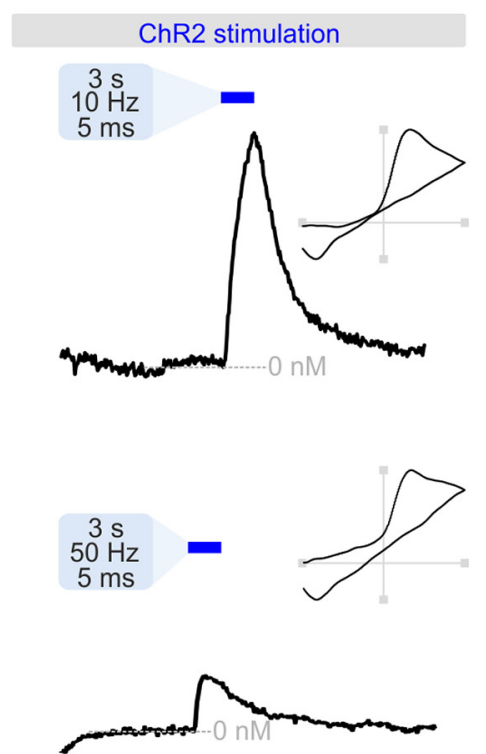

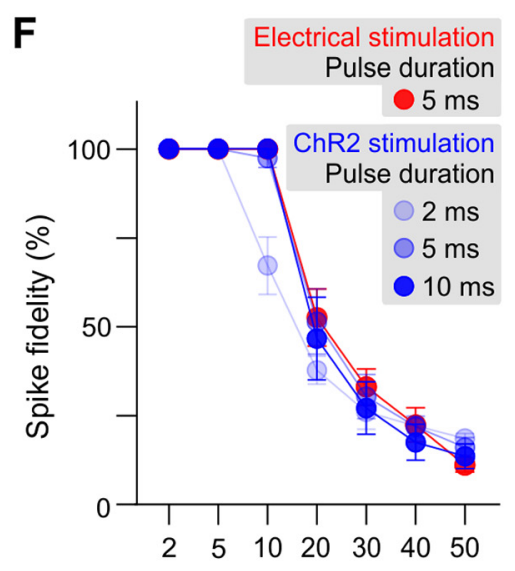

Stimulation frequency $(\mathrm{Hz})$

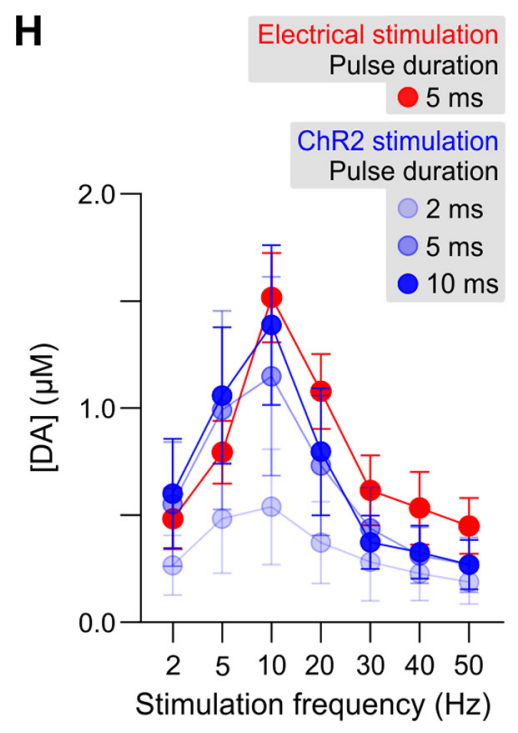

Figure 4. TIDA neuron endogenous firing frequency and optimal dopamine release in the ME terminals occur at $10 \mathrm{~Hz}$. $A$, Whole-cell recording from a DAT-tdTomato neuron, with one UP state shown in expanded temporal resolution (gray box below; action potentials [AP] truncated for clarity). $\boldsymbol{B}$, Quantification of the instantaneous firing frequency (IFF) of AP in an UP state ( $N=33$ cells, one-way ANOVA, $p<0.0001$; Table 1). C, Frequency distribution of IFF shows that the majority of spikes are discharged at $10 \mathrm{~Hz}$. D. ChR2 current at the peak and steady state, mediated via $1 \mathrm{~s}$ photostimulation $(N=6$, two-tailed paired $t$ test, $p=0.0073$; Table 1). $\boldsymbol{E}$, Representative traces with electrical square pulses and ChR2-driven AP firing at 10 and $50 \mathrm{~Hz}$. The depolarization block and low fidelity are at $50 \mathrm{~Hz}$. F, Quantification of spike fidelity versus photostimulation frequency and pulse width (repeated-measures one-way ANOVA; Table 1). G, Representative FSCV traces with electrically and ChR2-evoked dopamine release in the $\mathrm{ME}$ at 10 and $50 \mathrm{~Hz}$. $\boldsymbol{H}$, Quantification of dopamine release in the ME versus photostimulation frequency and pulse width (repeated-measures one-way ANOVA; Table 1). ${ }^{*} p<0.05,{ }^{* *} p<0.01,{ }^{* * *} p<0.001,{ }^{* * * *} p<0.0001$. Data are mean \pm SEM.

(Fig. 2G,H; Table 1). Finally, coapplication of $\mathrm{CdCl}_{2}(400 \mu \mathrm{M})$ abolished the release of dopamine (Fig. 4G,H; Table 1). Together, these data suggest that dopamine release in the tuberoinfundibular pathway is both action potential- and $\mathrm{Ca}^{2+}$-dependent and thus relies on similar mechanisms as in other systems.
Frequency preference for maximal dopamine release at the level of the terminals matches the endogenous average firing frequency of TIDA neurons

The majority of action potentials in the UP states of spontaneously active TIDA neurons (Fig. $4 \mathrm{~A}$ ) are discharged within a $\sim 10$ 

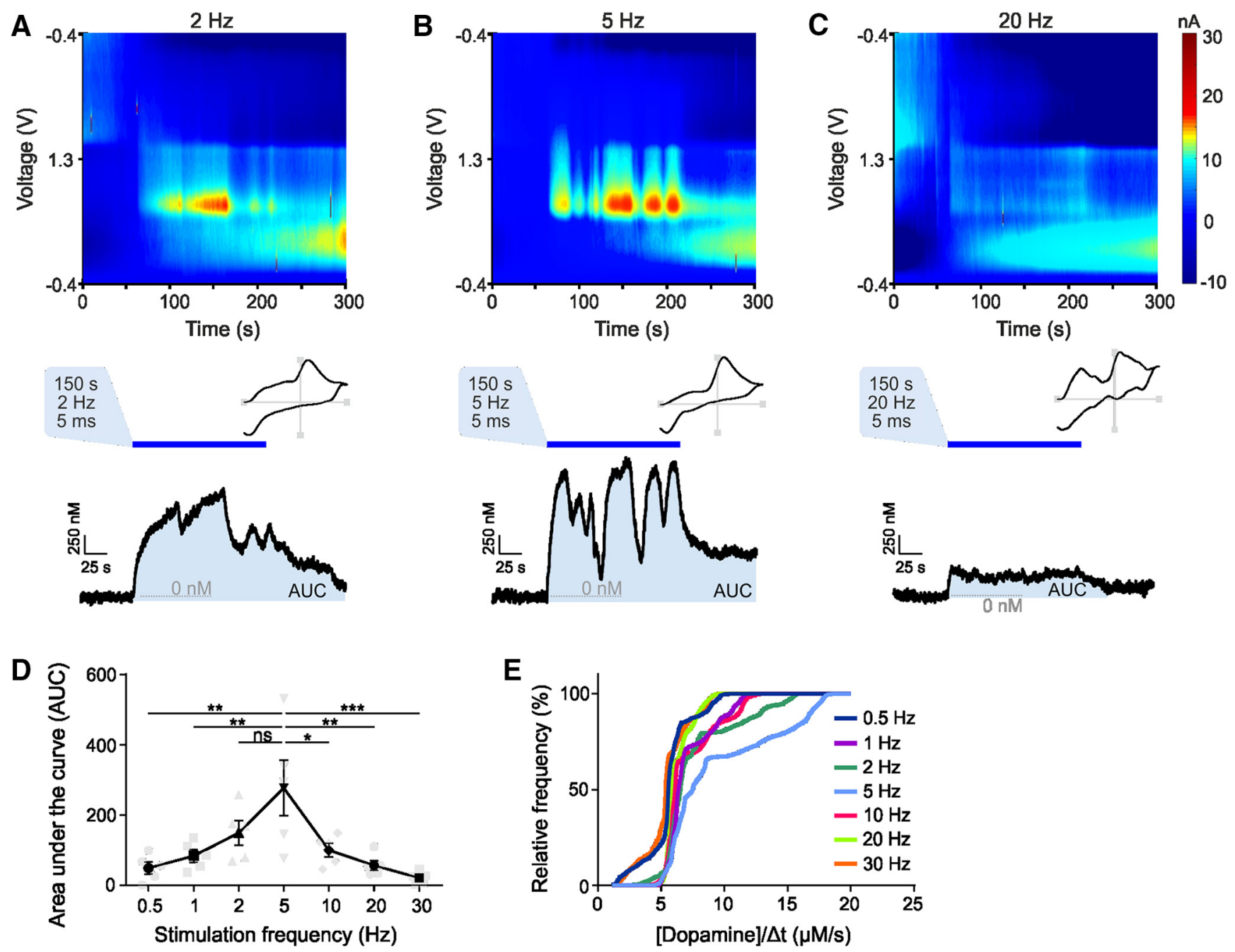

Figure 5. In tonic firing configuration, TIDA terminals release maximal amounts of dopamine in the ME at $5 \mathrm{~Hz}$. $\boldsymbol{A}$-C , Representative FSCV traces and heat maps with ChR2-evoked dopamine release in the ME at 2, 5, and $20 \mathrm{~Hz}$. D, Quantification of dopamine release in the ME versus photostimulation frequency with $5 \mathrm{~ms}$ pulse width $(\mathrm{N}=5$, repeated-measures one-way ANOVA, $p=$ 0.0004 ; Table 1). $E$, Relative frequency of dopamine release per second in the ME versus photostimulation frequency with 5 ms pulse width. ${ }^{*} p<0.05,{ }^{* *} p<0.01,{ }^{* * *} p<0.001,{ }^{* * * *} p<0.0001$. Data are mean \pm SEM.

Hz frequency (Fig. $4 B ; N=33, F_{(14,338)}=17.08, \mathrm{df}=14, p<$ 0.0001, one-way ANOVA with Tukey's test; Table 1), and the instantaneous frequency follows a normal-like distribution with a peak at $10.02 \mathrm{~Hz}$ (Fig. $4 A, C$ ). Following the characterization of the ChR2-mediated current with a fast and a slow component (Fig. $4 D ; N=6, t=4.357, \mathrm{df}=5, p=0.0073$, two-tailed paired $t$ test; Table 1) in somatic recordings, we investigated the spike fidelity of the TIDA cells at different electrically and optically evoked stimulation frequencies. Electrical or optogenetic stimulation of DAT-Cre neurons at frequencies of $\leq 10 \mathrm{~Hz}$ yielded a $100 \%$ spike fidelity (Fig. 4E, top, F; Table 1), whereas higher photostimulation frequencies $(30-50 \mathrm{~Hz})$ led to a depolarization block phase with substantial spike failure (Fig. $4 E$, bottom, F; Table 1). The latter phenomenon has previously been described in rat TIDA cells in response to pharmacological manipulations (Stagkourakis et al., 2016).

Based on the observation that spontaneous TIDA discharge is strongly biased to the $10 \mathrm{~Hz}$ frequency band, we next addressed whether transmitter release at the TIDA terminals responds differentially at different stimulation frequencies. To investigate this issue, a brief ( $3 \mathrm{~s}$ ) electrical or optical stimulation protocol was applied at frequencies ranging from 2 to $50 \mathrm{~Hz}$. Electrically evoked dopamine release was investigated in WT mice of C57BL/6J background, whereas optically evoked dopamine measurements were performed in ChR2 transduced DAT-Cre mice of the C57BL/6J background. Maximal dopamine release was recorded at $10 \mathrm{~Hz}$ using both methods of stimulation, with both higher and lower frequencies eliciting less dopamine signal (Fig. 4G,H). Importantly, the $10 \mathrm{~Hz}$ frequency yielded optimal dopamine release regardless of pulse duration when using a photostimulation protocol (Fig. 4H; Table 1). Together, these data suggest that the membrane properties of TIDA neurons, at the somatodendritic and axon terminal levels, are optimized to both discharge and release neurotransmitter content at 10 $\mathrm{Hz}$.

As dopamine release dynamics may vary between short and long bouts of activity, we repeated the analysis of the frequency and pulse duration dependence of dopamine release using a longer-duration (150 s) photostimulation protocol. The maximal dopamine release signal was also here biased toward the slower frequencies, with the greatest value recorded at $5 \mathrm{~Hz}$ (Fig. $5 A-E$; Table 1). Interestingly, the average firing frequency of suprathreshold oscillating TIDA neurons recorded in vitro is detected in that range (Fig. 3C,D). 
A

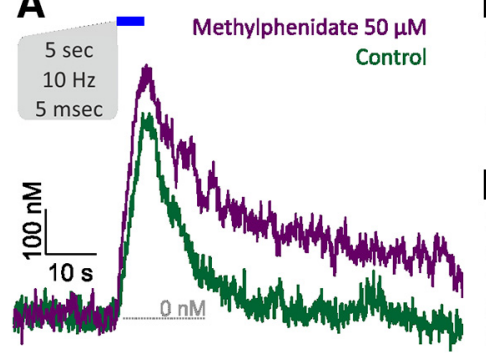

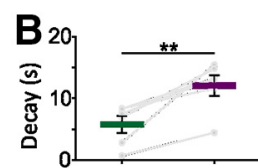

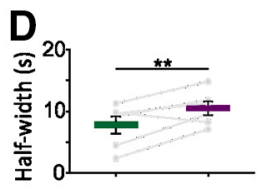

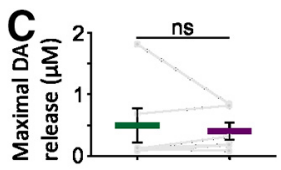

E

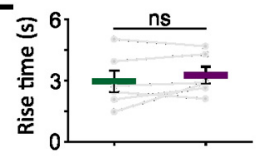

Figure 6. Dopamine release dynamics in the ME change upon DAT blockade. $A$, Representative dopamine-evoked oxidative current on baseline (green) and during (purple) DAT blockade with methylphenidate. $\boldsymbol{B}-\boldsymbol{E}$, Quantification of dopamine reuptake parameters, such as decay $(\boldsymbol{B})$, maximal amplitude of dopamine release $(\boldsymbol{C})$, half-width $(\boldsymbol{D})$, and rise time $(\boldsymbol{E})(\boldsymbol{N}=6$, two-tailed paired $t$ test; Table 1). ${ }^{*} p<0.05,{ }^{* *} p<0.01,{ }^{* * *} p<0.001,{ }^{* * * *} p<0.0001$. Data are mean \pm SEM.

\section{Functional DAT in the ME}

The expression of DAT in TIDA neurons is well documented (Meister and Elde, 1993; Revay et al., 1996; Demaria et al., 2000; Stagkourakis et al., 2018), yet the functional role of the transporter within the lactotropic axis remains controversial (Demarest and Moore, 1979; Annunziato et al., 1980; Meister and Elde, 1993; Revay et al., 1996; Bossé et al., 1997; Demaria et al., 2000; Stagkourakis et al., 2018). To assess whether reuptake is involved at determining dopamine levels at the entry to the portal vasculature, we performed optogenetic stimulation of TIDA terminals in the ME, in the absence and presence of the clinically prescribed DAT blocker, methylphenidate (Taylor and Ho, 1978; Volkow et al., 1999a, b). Following application of methylphenidate (10 $\mu \mathrm{M}$; Fig. 6A), the photostimulation-induced dopamine signal was augmented, quantified as prolonged decay (Fig. $6 B ; N=6, t=$ 4.439, $\mathrm{df}=5, p=0.0068$, two-tailed paired $t$ test) and half-width (Fig. $6 D ; N=6, t=5.228, \mathrm{df}=5, p=0.0034$, two-tailed paired $t$ test), whereas maximal [dopamine] release and rise time were not affected (Fig. 6C,D; Table 1). These data suggest the presence of functional dopamine transport active in the ME.

\section{Capacity for dopamine release at the somatodendritic compartment of TIDA neurons}

Recent work has suggested that local release of dopamine around the cell body and dendrites of TIDA neurons may serve as a critical component of an ultrashort feedback loop that tunes the electrical activity of these neurons to their recent transmitter secretion history (Belousov and van den Pol, 1997; Durham et al., 1998; Liang and Pan, 2012; Liang et al., 2014; Stagkourakis et al., 2016). Yet to date, no direct evidence exists that dopamine can indeed be released in the somatodendritic compartment in the dmArc. To investigate this possibility, TIDA cells were transduced with ChR2-eYFP. Inspection of cryostat sections of the dmArc of such animals revealed that the ChR2 construct was distributed on both cell bodies and dendrites of DAT-tdTomatopositive neurons (Fig. 7A). We next performed FSCV recordings in the dmArc with the carbon fiber electrode placed in the area occupied by TIDA cell somata (Fig. 7B). As in the ME, no spontaneous release could be recorded. When photostimulation was performed using the $5 \mathrm{~s}$ duration/10 $\mathrm{Hz} / 5 \mathrm{~ms}$ pulse protocol found to evoke optimal release in the ME (Fig. $4 H$ ), however, a distinct dopamine signal could be recorded (Fig. 7C,D). This signal was typically 10 - to 20 -fold below that recorded in the $\mathrm{ME}$ (compare Fig. $7 \mathrm{D}$ and Fig. $4 \mathrm{H}$ ). A photostimulation artifact is evident at $\sim 0$ and $1.3 \mathrm{~V}$ in the voltammogram, similar to what has been described previously (Bass et al., 2013). These results provide strong evidence for a capacity for dopamine release at the cell body level of TIDA neurons.

\section{Discussion}

The ability of a neuron to translate electrical activity to chemical signal is a core feature of the nervous system. Studies of dopamine transmission in the basal ganglia (Oleson et al., 2009; L. Zhang et al., 2009; Bass et al., 2010; Sulzer et al., 2016) have identified several principles of stimulus-secretion coupling. Yet, the specific volume and coding mechanisms of release used by different brain systems are likely to vary depending on their role in behavior and physiology. Here we addressed this issue in the neuroendocrine tuberoinfundibular system, where transmitter release from TIDA neurons can be monitored by FSCV while TIDA spiking patterns can be controlled by optogenetic stimulation.

We show that, while mouse TIDA neurons are able to spike across a spectrum of frequencies, in agreement with previous studies (Romanò et al., 2013, X. Zhang and van den Pol, 2015; Stagkourakis et al., 2018), action potentials are primarily discharged within a $10 \mathrm{~Hz}$ frequency band. When depolarized with greater stimulation than required to reach this frequency, TIDA neurons are successively more prone to depolarization block and spike failure (Stagkourakis et al., 2016; and present data). Importantly, maximal dopamine release was accomplished with a $10 \mathrm{~Hz}$ stimulation frequency (concomitant with full spike fidelity) and was abolished by the $\mathrm{Na}^{+}$channel blocker TTX. Partial recovery was achieved via coapplication of TTX and the potassium channel blocker 4-AP (Petreanu et al., 2009), whereas coapplication of TTX, 4-AP, and the generic $\mathrm{Ca}^{2+}$ channel blocker $\mathrm{CdCl}_{2}$ (Swandulla and Armstrong, 1989) abolished dopamine release at the TIDA terminals, suggesting that the dopamine thus recorded is the result of an action potential- and $\mathrm{Ca}^{2+}$-dependent process. Thus, the system appears to be operating at full capacity at its default spike rate (although it should be borne in mind that in vivo discharge frequencies, currently not known for the TIDA system, may be different). These results were recorded with $3 \mathrm{~s}$ stimulation bouts, in the range of the typical TIDA oscillation UP state in subthreshold oscillating cells (Stagkourakis et al., 2018). For extended periods (150 s) of stimulation, the optimal frequency was shifted toward slower frequencies. In the context of these findings, it can be noted that sustained (tonic) firing is triggered in TIDA neurons by modulators associated with inhibition of prolactin release upon central administration (Lyons et al., 2010; Briffaud et al., 2015). The firing frequency during this transmitter/hormone-induced persistent discharge can be lower than in the oscillatory state (Lyons et al., 2010), which may then offer an adaptation to the extended firing/lower frequency principle for optimal transmitter release suggested by the present data.

The dopamine concentration elicited by optogenetic stimulation ranged within $\sim 0.5-1.5 \mu \mathrm{M}$, comparable with the levels found in striatal recordings of dopamine release (Sulzer et al., 2016). The comparison between brain regions is fraught with complications, but it may be speculated that the dopamine concentrations evoked in the ME are likely diluted in the portal blood before reaching the target (lactotroph cells in the pituitary), unlike striatal dopamine concentrations, which potentially act di- 

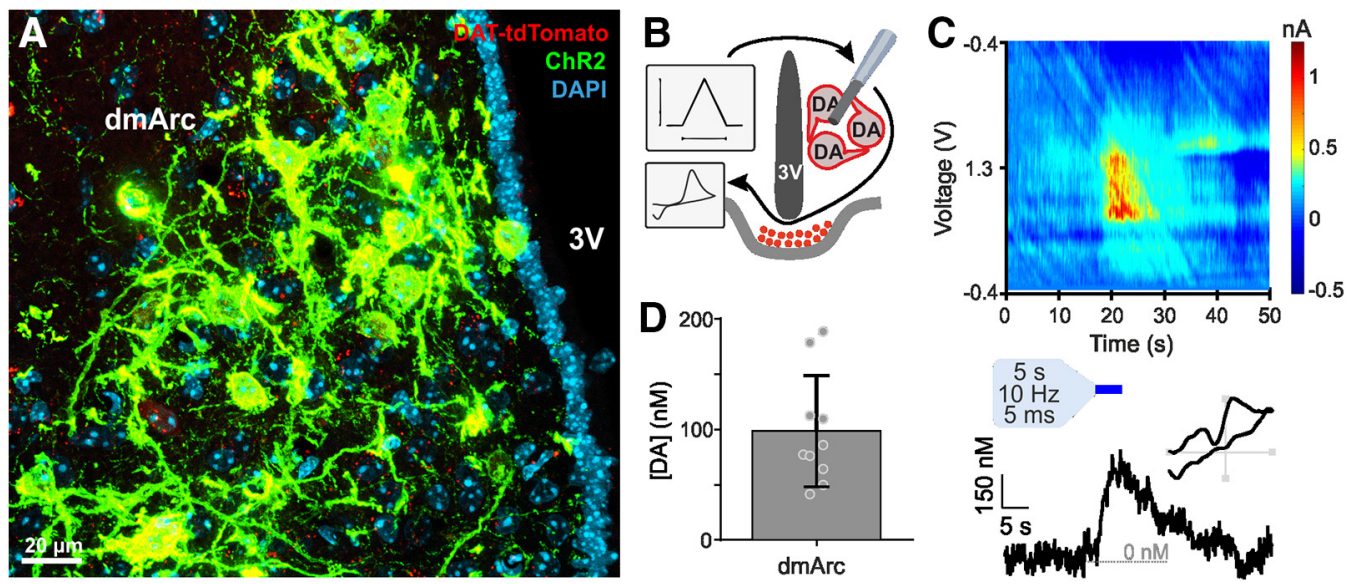

Figure 7. TIDA neurons release dopamine in the dmArc. $A$, Confocal Z-stack micrograph with virally mediated expression of ChR2-eYFP on DAT-tdTomato neurons in the dmArc. $B$, Experimental design of FSCV recordings aiming to record evoked dopamine release in dmArc. C, Representative FSCV trace with ChR2-evoked dopamine release in the dmArc. $\boldsymbol{D}$, Quantification of evokeddopamine release in dmArc. Data are mean \pm SEM. 3V, Third ventricle.

rectly on the postsynaptic cells (Ross, 1991; Korchounov et al., 2010). But an additional possibility could be that excess dopamine is necessary to compensate for the relatively less precise delivery of dopamine across the neurovascular interface and capillary distribution system compared with the point-to-point synaptic transmission in the striatum. It can also be noted that the levels we recorded are several magnitudes above those required for activation of D2R autoreceptors (Gonon and Buda, 1985), which may be present on the somatodendritic compartments or TIDA terminals (Berry and Gudelsky, 1991; Huang et al., 2013; Stagkourakis et al., 2016).

Previous in vitro (Romanò et al., 2013) and in vivo (Romanò et al., 2017) amperometry investigations have indicated that increased firing (induced by prolactin administration) in the TIDA ensemble correlates to higher amperometric signal at the terminal level, and that a range of release even frequencies can be detected in the ME in the intact animal. Yet, a comprehensive understanding of the coupling between TIDA neuron activity and dopamine release at the terminals has been lacking. The superior ability of FSCV over amperometry to identify transmitters with chemical selectivity (Bucher and Wightman, 2015), combined with the millisecond precision control spiking through optogenetics, has allowed us in the current study to correlate specific firing patterns to dopamine release volumes in the TIDA system, without contamination of other transmitters and metabolites.

The role of DAT in TIDA neurons has been a subject of controversy. Pharmacological studies of dopamine accumulation initially suggested that dopamine reuptake had a minor effect on ME levels, leading to conclusions that a transporter system was not reconcilable with vascular release (Demarest and Moore, 1979; Annunziato et al., 1980). This conclusion has, however, been challenged by subsequent studies using other DAT antagonists (Demaria et al., 2000) and genetic deletion (Bossé et al., 1997). Indeed, a functional role for DAT in TIDA terminals received early support from the demonstration that the dopamine metabolite, 3,4-dihydroxyphenylacetic acid, likely the result of metabolism following reuptake, is a well-correlated surrogate marker for dopamine in the ME (Lookingland et al., 1987). Here, we show that optogenetically elicited dopamine release at the ME is powerfully amplified in the presence of methylphenidate, a clinically used antagonist of DAT. It is important to remember in this context that neuroendocrine neurons do not make immedi- ate contact with portal capillaries, but rather abut a perivascular space (Ajika and Hökfelt, 1973) where release is postulated to occur. This organization suggests that secreted dopamine may linger for a period in the proximity of the terminal before ending up in the bloodstream, allowing for a window of opportunity for transmitter reuptake.

Recently, we have proposed the existence of an ultrashort D2R-mediated feedback loop (Stagkourakis et al., 2016). This model is primarily based on pharmacological and electrophysiological findings, but a key component of this scheme is the existence of release of ambient dopamine at the somatodendritic compartment, for which evidence has been lacking. The present study shows that release of dopamine can be triggered at the cell body level through optogenetic stimulation. Notably, the levels thus elicited were approximately a magnitude lower than what was recorded in the ME with similar stimulation. Our model proposes that local dmArc release mirrors fluctuations at the $\mathrm{ME}$, but need not do so at similar absolute concentrations. Thus, the current findings support the existence of an autoinhibitory feedback loop. The exact release site for this evoked dopamine remains to be determined. Ultrastructural studies have demonstrated that TIDA neurons extend recurrent collaterals that project toward, but do not make direct contact with, TIDA cell bodies (Piotte et al., 1985), which could be providing extrasynaptic dopamine. There are, however, also dense dendrodendritic and somatodendritic contacts within the TIDA population (Piotte et al., 1985). In the midbrain, such contacts have been implicated in local release from the soma and/or dendrites (Hefti and Lichtensteiger, 1978; Cheramy et al., 1981; Rice and Patel, 2015). The current findings suggest that this possibility merits further investigation in the TIDA system.

In conclusion, the present data show how dopamine dynamics in the TIDA system correlate to spike rates, and identify regulatory mechanisms involved in this process at both the terminal and somatodendritic level. These findings offer insight into the relationship between electrical activity and signal substance release in the neuroendocrine system, and provide a platform for further investigations of stimulus-secretion coupling in the hypothalamo-pituitary axis.

\section{References}

Ajika K, Hökfelt T (1973) Ultrastructural identification of catecholamine neurones in the hypothalamic periventricular-arcuate nucleus-median 
eminence complex with special reference to quantitative aspects. Brain Res 57:97-117.

Annunziato L, Leblanc P, Kordon C, Weiner RI (1980) Differences in the kinetics of dopamine uptake in synaptosome preparations of the medianeminence relative to other dopaminergically innervated brain-regions. Neuroendocrinology 31:316-320.

Bass CE, Grinevich VP, Vance ZB, Sullivan RP, Bonin KD, Budygin EA (2010) Optogenetic control of striatal dopamine release in rats. J Neurochem 114:1344-1352.

Bass CE, Grinevich VP, Kulikova AD, Bonin KD, Budygin EA (2013) Terminal effects of optogenetic stimulation on dopamine dynamics in rat striatum. J Neurosci Methods 214:149-155.

Baur JE, Kristensen EW, May LJ, Wiedemann DJ, Wightman RM (1988) Fast-scan voltammetry of biogenic amines. Anal Chem 60:1268-1272.

Belousov AB, van den Pol AN (1997) Dopamine inhibition: enhancement of GABA activity and potassium channel activation in hypothalamic and arcuate nucleus neurons. J Neurophysiol 78:674-688.

Berry SA, Gudelsky GA (1991) Effect of D2 dopamine agonists on tuberoinfundibular dopamine neurons. Neuropharmacology 30:961-965.

Bossé R, Fumagalli F, Jaber M, Giros B, Gainetdinov RR, Wetsel WC, Missale C, Caron MG (1997) Anterior pituitary hypoplasia and dwarfism in mice lacking the dopamine transporter. Neuron 19:127-138.

Briffaud V, Williams P, Courty J, Broberger C (2015) Excitation of Tuberoinfundibular Dopamine Neurons by Oxytocin: Crosstalk in the Control of Lactation. Journal of Neuroscience 35:4229-4237.

Brimblecombe KR, Gracie CJ, Platt NJ, Cragg SJ (2015) Gating of dopamine transmission by calcium and axonal N-, Q-, T- and L-type voltage-gated calcium channels differs between striatal domains. J Physiol 593:929-946.

Brouwers B, de Faudeur G, Osipovich AB, Goyvaerts L, Lemaire K, Boesmans L, Cauwelier EJ, Granvik M, Pruniau VP, Van Lommel L, Van Schoors J, Stancill JS, Smolders I, Goffin V, Binart N, in't Veld P, Declercq J, Magnuson MA, Creemers JW, Schuit F, et al. (2014) Impaired islet function in commonly used transgenic mouse lines due to human growth hormone minigene expression. Cell Metab 20:979-990.

Bucher ES, Wightman RM (2015) Electrochemical analysis of neurotransmitters. Annu Rev Anal Chem 8:239-261.

Buteau H, Pezet A, Ferrag F, Perrot-Applanat M, Kelly PA, Edery M (1998) $\mathrm{N}$-glycosylation of the prolactin receptor is not required for activation of gene transcription but is crucial for its cell surface targeting. Mol Endocrinol 12:544-555.

Cheramy A, Leviel V, Glowinski J (1981) Dendritic release of dopamine in the substantia nigra. Nature 289:537-542.

Del Castillo J, Katz B (1954) Quantal components of the end-plate potential. J Physiol 124:560-573.

Demarest KT, Moore KE (1979) Lack of a high-affinity transport-system for dopamine in the median-eminence and posterior pituitary. Brain Res 171:545-551.

Demaria JE, Nagy GM, Lerant AA, Fekete MI, Levenson CW, Freeman ME (2000) Dopamine transporters participate in the physiological regulation of prolactin. Endocrinology 141:366-374.

Doussau F, Schmidt H, Dorgans K, Valera AM, Poulain B, Isope P (2017) Frequency-dependent mobilization of heterogeneous pools of synaptic vesicles shapes presynaptic plasticity. eLife 6:e28935.

Durham RA, Johnson JD, Eaton MJ, Moore KE, Lookingland KJ (1998) Opposing roles for dopamine D-1 and D-2 receptors in the regulation of hypothalamic tuberoinfundibular dopamine neurons. Eur J Pharmacol 355:141-147.

Ekstrand MI, Terzioglu M, Galter D, Zhu S, Hofstetter C, Lindqvist E, Thams S, Bergstrand A, Hansson FS, Trifunovic A, Hoffer B, Cullheim S, Mohammed AH, Olson L, Larsson NG (2007) Progressive parkinsonism in mice with respiratory-chain-deficient dopamine neurons. Proc Natl Acad Sci U S A 104:1325-1330.

Franklin KB, Paxinos G (2008) The mouse brain in stereotactic coordinates, Ed 3. San Diego: Academic.

Garris PA, Christensen JR, Rebec GV, Wightman RM (1997) Real-time measurement of electrically evoked extracellular dopamine in the striatum of freely moving rats. J Neurochem 68:152-161.

Glanowska KM, Venton BJ, Moenter SM (2012) Fast scan cyclic voltammetry as a novel method for detection of real-time gonadotropin-releasing hormone release in mouse brain slices. J Neurosci 32:14664-14669.

Goffin V, Kelly PA (1997) The prolactin/growth hormone receptor family: structure/function relationships. J Mammary Gland Biol Neoplasia 2:7-17.

Gonon FG, Buda MJ (1985) Regulation of dopamine release by impulse flow and by autoreceptors as studied by in vivo voltammetry in the rat striatum. Neuroscience 14:765-774.

Grattan DR (2015) 60 years of neuroendocrinology the hypothalamoprolactin axis. J Endocrinol 226:T101-T122.

Gudelsky GA (1981) Tuberoinfundibular dopamine neurons and the regulation of prolactin secretion. Psychoneuroendocrinology 6:3-16.

Harris GW (1948a) Electrical stimulation of the hypothalamus and the mechanism of neural control of the adenohypophysis. J Physiol 107:418-429.

Harris GW (1948b) Neural control of the pituitary gland. Physiol Rev 28:139-179.

Hefti F, Lichtensteiger W (1978) Dendritic dopamine: studies on release of endogenous dopamine from subcellular particles derived from dendrites of rat nigro-striatal neurons. Neurosci Lett 10:65-70.

Huang R, Griffin SA, Taylor M, Vangveravong S, Mach RH, Dillon GH, Luedtke RR (2013) The effect of SV 293, a D2 dopamine receptorselective antagonist, on D2 receptor-mediated GIRK channel activation and adenylyl cyclase inhibition. Pharmacology 92:84-89.

Israel JM, Kukstas LA, Vincent JD (1990) Plateau potentials recorded from lactating rat enriched lactotroph cells are triggered by thyrotropinreleasing-hormone and shortened by dopamine. Neuroendocrinology 51: 113-122.

Iverfeldt K, Serfözö P, Diaz Arnesto L, Bartfai T (1989) Differential release of coexisting neurotransmitters: frequency dependence of the efflux of substance-P, thyrotropin releasing hormone and $[\mathrm{H}-3]$ serotonin from tissue-slices of rat ventral spinal cord. Acta Physiol Scand 137:63-71.

Korchounov A, Meyer MF, Krasnianski M (2010) Postsynaptic nigrostriatal dopamine receptors and their role in movement regulation. J Neural Transm 117:1359-1369.

Kosillo P, Zhang YF, Threlfell S, Cragg SJ (2016) Cortical control of striatal dopamine transmission via striatal cholinergic interneurons. Cereb Cortex 26:4160-4169.

Liang SL, Pan JT (2012) An endogenous dopaminergic tone acting on dopamine D-3 receptors may be involved in diurnal changes of tuberoinfundibular dopaminergic neuron activity and prolactin secretion in estrogen-primed ovariectomized rats. Brain Res Bull 87:334-339.

Liang SL, Hsu SC, Pan JT (2014) Involvement of dopamine D2 receptor in the diurnal changes of tuberoinfundibular dopaminergic neuron activity and prolactin secretion in female rats. J Biomed Sci 21:37.

Liu X, Porteous R, d'Anglemont de Tassigny X, Colledge WH, Millar R, Petersen SL, Herbison AE (2011) Frequency-dependent recruitment of fast amino acid and slow neuropeptide neurotransmitter release controls gonadotropin-releasing hormone neuron excitability. J Neurosci 31: 2421-2430.

Lledo PM, Legendre P, Israel JM, Vincent JD (1990) Dopamine inhibits 2 characterized voltage-dependent calcium currents in identified rat lactotroph cells. Endocrinology 127:990-1001.

Lookingland KJ, Jarry HD, Moore KE (1987) The metabolism of dopamine in the median eminence reflects the activity of tuberoinfundibular neurons. Brain Res 419:303-310.

Lyons DJ, Broberger C (2014) TIDAL WAVES: network mechanisms in the neuroendocrine control of prolactin release. Front Neuroendocrinol 35: $420-438$.

Lyons DJ, Horjales-Araujo E, Broberger C (2010) Synchronized network oscillations in rat tuberoinfundibular dopamine neurons: switch to tonic discharge by thyrotropin-releasing hormone. Neuron 65:217-229.

Malgaroli A, Vallar L, Elahi FR, Pozzan T, Spada A, Meldolesi J (1987) Dopamine inhibits cytosolic-Ca- ${ }^{2+}$ increases in rat lactotroph cells: evidence of a dual mechanism of action. J Biol Chem 262:13920-13927.

Meister B, Elde R (1993) Dopamine transporter mRNA in neurons of the rat hypothalamus. Neuroendocrinology 58:388-395.

Melchior JR, Jones SR (2017) Chronic ethanol exposure increases inhibition of optically targeted phasic dopamine release in the nucleus accumbens core and medial shell ex vivo. Mol Cell Neurosci 85:93-104.

Melchior JR, Ferris MJ, Stuber GD, Riddle DR, Jones SR (2015) Optogenetic versus electrical stimulation of dopamine terminals in the nucleus accumbens reveals local modulation of presynaptic release. J Neurochem 134: 833-844.

Ngodup T, Goetz JA, McGuire BC, Sun W, Lauer AM, Xu-Friedman MA 
(2015) Activity-dependent, homeostatic regulation of neurotransmitter release from auditory nerve fibers. Proc Natl Acad Sci U S A 112:64796484.

Oleson EB, Salek J, Bonin KD, Jones SR, Budygin EA (2009) Real-time voltammetric detection of cocaine-induced dopamine changes in the striatum of freely moving mice. Neurosci Lett 467:144-146.

O'Neill B, Patel JC, Rice ME (2017) Characterization of optically and electrically evoked dopamine release in striatal slices from digenic knock-in mice with DAT-driven expression of channelrhodopsin. ACS Chem Neurosci 8:310-319.

Petreanu L, Mao T, Sternson SM, Svoboda K (2009) The subcellular organization of neocortical excitatory connections. Nature 457:1142-1145.

Piotte M, Beaudet A, Joh TH, Brawer JR (1985) The fine structural organization of tyrosine hydroxylase immunoreactive neurons in rat arcuate nucleus. J Comp Neurol 239:44-53.

Revay R, Vaughan R, Grant S, Kuhar MJ (1996) Dopamine transporter immunohistochemistry in median eminence, amygdala, and other areas of the rat brain. Synapse 22:93-99.

Rice ME, Patel JC (2015) Somatodendritic dopamine release: recent mechanistic insights. Philos Trans R Soc London B Biol Sci 370:20140185.

Robinson DL, Venton BJ, Heien ML, Wightman RM (2003) Detecting subsecond dopamine release with fast-scan cyclic voltammetry in vivo. Clin Chem 49:1763-1773.

Rodeberg NT, Sandberg SG, Johnson JA, Phillips PE, Wightman RM (2017) Hitchhiker's guide to voltammetry: acute and chronic electrodes for in vivo fast-scan cyclic voltammetry. ACS Chem Neurosci 8:221-234.

Romanò N, Yip SH, Hodson DJ, Guillou A, Parnaudeau S, Kirk S, Tronche F, Bonnefont X, Le Tissier P, Bunn SJ, Grattan DR, Mollard P, Martin AO (2013) Plasticity of hypothalamic dopamine neurons during lactation results in dissociation of electrical activity and release. J Neurosci 33:4424-4433.

Romanò N, Guillou A, Hodson DJ, Martin AO, Mollard P (2017) Multiplescale neuroendocrine signals connect brain and pituitary hormone rhythms. Proc Natl Acad Sci U S A 114:2379-2382.

Ross SB (1991) Synaptic concentration of dopamine in the mouse striatum in relationship to the kinetic properties of the dopamine receptors and uptake mechanism. J Neurochem 56:22-29.

Stagkourakis S, Kim H, Lyons DJ, Broberger C (2016) Dopamine autore- ceptor regulation of a hypothalamic dopaminergic network. Cell Rep 15:735-747.

Stagkourakis S, Pérez CT, Hellysaz A, Ammari R, Broberger C (2018) Network oscillation rules imposed by species-specific electrical coupling. eLife 7:e33144.

Stefaneanu L, Kovacs K, Scheithauer BW, Kontogeorgos G, Riehle DL, Sebo TJ, Murray D, Vidal S, Tran A, Buchfelder M, Fahlbusch R (2000) Effect of dopamine agonists on lactotroph adenomas of the human pituitary. Endocr Pathol 11:341-352.

Sulzer D, Cragg SJ, Rice ME (2016) Striatal dopamine neurotransmission: regulation of release and uptake. Basal Ganglia 6:123-148.

Swandulla D, Armstrong CM (1989) Calcium channel block by cadmium in chicken sensory neurons. Proc Natl Acad Sci U S A 86:1736-1740.

Taylor D, Ho BT (1978) Comparison of inhibition of monoamine uptake by cocaine, methylphenidate and amphetamine. Res Commun Chem Pathol Pharmacol 21:67-75.

Threlfell S, Lalic T, Platt NJ, Jennings KA, Deisseroth K, Cragg SJ (2012) Striatal dopamine release is triggered by synchronized activity in cholinergic interneurons. Neuron 75:58-64.

van den Pol AN, Cassidy JR (1982) The hypothalamic arcuate nucleus of rat-a quantitative Golgi analysis. J Comp Neurol 204:65-98.

Volkow ND, Fowler JS, Gatley SJ, Dewey SL, Wang GJ, Logan J, Ding YS, Franceschi D, Gifford A, Morgan A, Pappas N, King P (1999a) Comparable changes in synaptic dopamine induced by methylphenidate and by cocaine in the baboon brain. Synapse 31:59-66.

Volkow ND, Wang GJ, Fowler JS, Fischman M, Foltin R, Abumrad NN, Gatley SJ, Logan J, Wong C, Gifford A, Ding YS, Hitzemann R, Pappas N (1999b) Methylphenidate and cocaine have a similar in vivo potency to block dopamine transporters in the human brain. Life Sci 65:PL7-PL12.

Zhang L, Doyon WM, Clark JJ, Phillips PE, Dani JA (2009) Controls of tonic and phasic dopamine transmission in the dorsal and ventral striatum. Mol Pharmacol 76:396-404.

Zhang X, van den Pol AN (2015) Dopamine/tyrosine hydroxylase neurons of the hypothalamic arcuate nucleus release GABA, communicate with dopaminergic and other arcuate neurons, and respond to dynorphin, met-enkephalin, and oxytocin. J Neurosci 35:14966-14982. 